OPEN ACCESS

Edited by:

Martin Walter,

University of Tübingen, Germany

Reviewed by:

Eva Brandl,

Charité Medical University of Berlin,

Germany

Carsten Culmsee,

University of Marburg, Germany

*Correspondence:

Hubertus Himmerich

hubertus.himmerich@kcl.ac.uk

Specialty section: This article was submitted to Mood and Anxiety Disorders, a section of the journal Frontiers in Psychiatry

Received: 04 September 2018 Accepted: 18 January 2019

Published: 07 February 2019

Citation

Himmerich H, Patsalos O, Lichtblau N, Ibrahim MAA and Dalton B (2019) Cytokine Research in Depression: Principles, Challenges, and Open

Questions. Front. Psychiatry 10:30. doi: 10.3389/fpsyt.2019.00030

\section{Cytokine Research in Depression: Principles, Challenges, and Open Questions}

\author{
Hubertus Himmerich ${ }^{1,2 *}$, Olivia Patsalos ${ }^{1}$, Nicole Lichtblau ${ }^{3}$, Mohammad A. A. Ibrahim ${ }^{4}$ \\ and Bethan Dalton ${ }^{1}$
}

${ }^{1}$ Department of Psychological Medicine, Institute of Psychiatry, Psychology \& Neuroscience, King's College London, London, United Kingdom, ${ }^{2}$ South London and Maudsley NHS Foundation Trust, London, United Kingdom, ${ }^{3}$ Maidstone and Tunbridge Wells NHS Trust, Maidstone, United Kingdom, ${ }^{4}$ Department of Clinical Immunological Medicine and Allergy, King's Health Partners, King's College Hospital, London, United Kingdom

Cytokines have been implicated in the pathology of depression. Currently, the evidence is based on cross-sectional studies and meta-analytic research comparing blood concentrations of $T$ helper type $1\left(T_{H} 1\right)$, $T$ helper type $2\left(T_{H} 2\right)$, pro-inflammatory or anti-inflammatory cytokines of patients with a depressive disorder to those of healthy controls. Additionally, multiple longitudinal studies have investigated cytokine levels during antidepressant treatment. According to the current literature, it seems that peripheral levels of interleukin (IL)-6, IL-10, IL-12, IL-13, and tumor necrosis factor (TNF)- $\alpha$ are elevated and that interferon (IFN)- $\gamma$ levels are lower in patients with depression compared to healthy controls. However, the overlap of cytokine values between acutely depressed patients, remitted and recovered patients and healthy controls is considerable. Thus, the discriminative power of cytokine concentrations between depressed and non-depressed people is likely weak. Treatment with certain antidepressants appears to decrease peripheral levels of IL-6, IL-10, and TNF- $\alpha$. However, weight gain-inducing psychopharmacological substances, such as the antidepressant mirtazapine, have been reported to potentially increase the production of pro-inflammatory cytokines. Even though cytokines are often discussed as biomarkers for depression, they have also been shown to be altered in other psychiatric disorders. Moreover, many environmental, social, psychological, biological, and medical factors are also associated with cytokine changes. Thus, cytokine alterations seem extremely unspecific. The interpretation of the results of these studies remains a challenge because it is unknown which type of cells are most responsible for cytokine changes measured in the blood nor have the main target cells or target tissues been identified. The same cytokine can be produced by multiple cell types, and the same cell can produce various cytokines. Additionally, redundancy, synergy, antagonism, and signaling cascades of cytokine signaling must be considered. Cytokines might not be associated with the diagnosis of depression according to the currently used diagnostic manuals, but rather with specific subtypes of depression, or with depressive symptoms across different psychiatric diagnoses. Therefore, the currently available diagnostic systems may not be the ideal starting point for psychiatric cytokine research.

Keywords: cytokine, interleukin, interferon, tumor necrosis factor, depression 


\section{INTRODUCTION}

\section{Aim of This Review Article}

The aim of this narrative review is to explain the fundamentals, implications, challenges, and limitations of cytokine research in depression. This comprises of:

- a brief explanation of what cytokines are,

- a short illustration of the historical developments leading to where we currently are in psychiatric cytokine research,

- an explanation of the physiological fundamentals of cytokine signaling within the immune system and the brain,

- a summary of how cytokines have been linked to depression, its risk factors and antidepressant therapy,

- a critical perspective on the limitations that researchers currently face while interpreting findings of cytokine research in depression.

Several recent meta-analyses have already summarized data on peripheral cytokine alterations in depression [e.g., $(1,2)]$ and during antidepressant therapy [e.g., (2)]. Therefore, this article intends to help to explain and interpret such findings in the current scientific literature. Results of animal studies, in vitro studies and research on serum or plasma levels of cytokines in patients with other psychiatric disorders will be mentioned, as this is necessary to understand the advantages and limitations of cytokine research in depression.

\section{Cytokines}

The term "cytokine" is a compound word derived from the ancient Greek language. Its first component " $\kappa \hat{v} \tau \mathrm{o}_{\zeta}$ " means

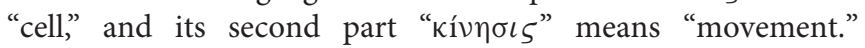
Cytokines are a broad and loose category of secreted proteins that are important in cell signaling. This group of messenger molecules includes chemokines, interferons (IFN), interleukins (IL), lymphokines, and tumor necrosis factors (TNF). Cytokines are produced by immune cells such as macrophages, B lymphocytes, $\mathrm{T}$ lymphocytes, and mast cells which are mobile within the body, as well as parenchymal cells. Thus, cytokine production is not bound to a specific organ, but can happen everywhere in the human organism. Apart from immune cells, other cells that release cytokines include endothelial cells, fibroblasts, and epithelial and stromal cells within the body's periphery, and microglia and astrocytes in the brain (3-6).

Cytokines are distinct from hormones and neurotransmitters $(7,8)$ which are other important signaling molecules in the body. Hormones are measured in less variable concentrations in the blood circulation and are usually produced and secreted by specific cells within endocrine glands. Neurotransmitters generally transmit signals across a chemical synapse, such as a neuromuscular junction, from one nerve cell to another, or from a nerve cell to gland cell (9). Most cytokines act in their immediate micro-environment. A few exert a hormone-like effect by being released in to the blood to act on distant organs, e.g., the cytokine mediators of the acute phase response, IL-1, IL-6, and TNF- $\alpha$ (10).

For further information about the differences and similarities between cytokines, hormones and neurotransmitters see Table 1.

\section{Historical Background of the Discovery of Cytokines and Their Importance for the Brain}

From the 1950s to the 1980s, the first cytokines and their functions were discovered. Among those important cytokines were IFN- $\alpha$ (12), IFN- $\gamma$ (13), the macrophage migration inhibitory factor (MIF) $(14,15)$, and TNF- $\alpha$ (16). Shortly after the discovery of the first cytokine, IFN- $\alpha$, it became clear that cytokines from the body's periphery can influence inflammatory processes in the brain $(17,18)$, that cytokines can be produced in the brain (18), and that immune cells are not the only cells that release cytokines (19). In addition to their role in steering the immune system to defend the body from pathogens (12) and tumors (16), their modifying effect on neurotransmission was discovered $(20,21)$. In the 1970 s, scientists started to understand that cytokines act via specific cytokine receptors on the surface of cells (22).

The first chemical analyses to measure cytokines were complicated by the low concentrations of cytokines in serum, plasma and tissue. For example, cytokines like TNF- $\alpha$ usually circulate in picomolar concentrations in the serum [e.g., (23)]. In contrast, classic hormones, for example cortisol, circulate in nanomolar concentrations [e.g., (24)]. The lack of assay systems was overcome by monoclonal antibody technology and the invention of the radio-immuno-assay (RIA) (25) and the enzyme-linked immunosorbant assays (ELISA) $(26,27)$. The RIA and ELISA allowed a highly sensitive measurement of cytokine concentrations. Further technical advancements have led to an abundance of methods to measure cytokines including bioassays, protein microarrays, high-performance liquid chromatography (HPLC), sandwich enzyme-linked immunosorbent assay (ELISA), Meso Scale Discovery (MSD) electrochemiluminescence and bead-based multiplex immunoassays (MIA) (28).

In the 1970s and 1980s, the first recombinant DNA molecules were generated (29) which allowed molecular cloning of a gene and the development of organisms that produce a protein product on the basis of such a cloned gene. Gene cloning allowed for the production of large amounts of recombinant cytokines (30).

\section{Difficulties of Cytokine Research in Psychiatry}

Cytokine research in psychiatry faces several difficulties, such as conflicting results and high variance of cytokine values within samples. Most of the studies measure serum or plasma cytokine levels, but it has often been discussed whether these results reflect the situation in the brain (31).

Cytokine research in affective disorders reflects these difficulties in an exemplary way. Even though most studies have found, for example, elevated levels of TNF- $\alpha$ in the serum or plasma of depressed patients $(32,33)$, such positive results have not been obtained by all studies, and heterogeneity of the results between studies is large (2). Results of cytokine research which are partly contradicting and often difficult to interpret have also been obtained in post-traumatic stress disorder (PTSD) (34-36) 
TABLE 1 | Synopsis of similarities and differences in characteristics of cytokines, hormones and neurotransmitters (7-9, 11).

\begin{tabular}{|c|c|c|c|}
\hline & Cytokines & Hormones & Neurotransmitters \\
\hline Chemical characteristics & - Secreted proteins & $\begin{array}{l}\text { - Derivatives of cholesterol } \\
\text { - Derivatives of amino acids } \\
\text { - Peptides } \\
\text { - Proteins }\end{array}$ & $\begin{array}{l}\text { - Gasotransmitters } \\
\text { - Amino acids } \\
\text { - Monoamines and trace } \\
\text { - } \text { amines } \\
\text { - Peptides } \\
\text { - Purines } \\
\text { - Fatty acids } \\
\text { - Acetylcholine }\end{array}$ \\
\hline Cells of origin & $\begin{array}{l}\text { - Immune cells } \\
\text { - Endothelial \& epithelial cells } \\
\text { - Fibroblasts } \\
\text { - Stromal cells } \\
\text { - Microglia, Astrocytes }\end{array}$ & - Cells of endocrine glands & - Nerve cells \\
\hline Target cells & $\begin{array}{l}\text { - Immune cells } \\
\text { - Nerve cells } \\
\text { - Principally all somatic cells }\end{array}$ & $\begin{array}{l}\text { - Cells of distant target organs } \\
\text { - Principally all somatic cells }\end{array}$ & $\begin{array}{l}\text { - Nerve cells } \\
\text { - Muscle cells } \\
\text { - Gland cells }\end{array}$ \\
\hline Concentration in the circulation & $\begin{array}{l}\text { - Picomolar } \\
\text { - Increase up to 1,000 times during } \\
\text { trauma or infection }\end{array}$ & $\begin{array}{l}\text { - Nanomolar } \\
\text { - Little variation }\end{array}$ & $\begin{array}{l}\text { - Spillover of } \\
\text { neurotransmitters into } \\
\text { the circulation only } \\
\text { under certain } \\
\text { circumstances }\end{array}$ \\
\hline Receptors & $\begin{array}{l}\text { - Transmembrane receptors linked to } \\
\text { - JAK-STAT pathway } \\
\text { - G-proteins } \\
\text { - NFKB }\end{array}$ & $\begin{array}{l}\text { - Transmembrane receptors linked to } \\
\text { - G-proteins } \\
\text { - Enzymes } \\
\text { - Intracellular receptors linked to } \\
\text { - DNA promotors }\end{array}$ & $\begin{array}{l}\text { - Transmembrane } \\
\text { ionotropic receptors: } \\
\text { - Neurotransmitter-gated } \\
\text { ion channel } \\
\text { - Transmembrane } \\
\text { metabotropic receptors } \\
\text { linked to } \\
\text { - G-proteins }\end{array}$ \\
\hline
\end{tabular}

and eating disorders (37). In order to understand the challenges and difficulties of cytokine research in psychiatry, one has to consider several characteristics of cytokine signaling and their role within the immune system. Therefore, the next sections will explain these mechanisms.

\section{Methods of This Review Article}

This is a narrative review; therefore, we did not apply strict selection criteria for the inclusion of certain articles. We rather selected articles based on how comprehensive, innovative, and clearly written they were and how much information they provided for an in-depth understanding and a critical debate of the topic. We included not only original research, but also reviews, book chapters and case reports. Regarding the section on cytokine alterations in depression and other psychiatric disorders, we strictly included only the latest meta-analysis on cytokine levels for each diagnosis in the text and in Table 2.

\section{CHARACTERISTICS OF CYTOKINE SIGNALING}

\section{Cytokine Release}

Cytokines mediate and regulate the immune system. Their secretion is brief and self-limited.
There are three main types of cytokine signaling: autocrine, paracrine and endocrine $(7,8,41)$. An example for autocrine signaling is a T-helper type $2\left(\mathrm{~T}_{\mathrm{H}} 2\right)$ cell which can stimulate its own growth by producing IL-4 (42). The way in which $\mathrm{T}_{\mathrm{H}} 2$ cells can also stimulate nearby $\mathrm{B}$ lymphocytes by releasing IL-4 is an example of paracrine signaling (43) and endocrine signaling can be illustrated by TNF- $\alpha$ which is produced by macrophages in the adipose tissue and secreted into circulation. This pro-inflammatory signal can contribute to inflammatory processes within the artery walls and eventually lead to arteriosclerosis (44). In the cases of trauma, infection, stress, neoplasia, and inflammation, the body activates a complex systemic early-defense system. This process is called acute phase response which is a specialized systemic innate immune response in which the cytokines IL-1, IL-6, and TNF- $\alpha$ act like hormones. They are released by innate immune cells at the sites of infection or inflammation and released into circulation to act on distant organs e.g., the liver, to mediate the release of acute phase reactants, e.g., C-reactive protein (CRP) (45).

The same cytokine can be produced by multiple cell types. For instance, TNF- $\alpha$ is released by white blood cells, the endothelium, fat cells and other cells (46). Furthermore, one single cell can produce different cytokines. For example, $\mathrm{T}_{\mathrm{H}} 2$ cells can produce IL-3, IL-4, IL-5, IL-6, and IL-13 (47). 
TABLE 2 | Summary of cytokine blood concentrations in the context of psychiatric disorders according to relevant meta-analyses (2, 36-40).

\begin{tabular}{|c|c|c|c|c|c|c|c|c|c|c|c|}
\hline \multirow[t]{2}{*}{ Diagnoses } & \multicolumn{10}{|c|}{ Cytokines } & \multirow[t]{2}{*}{ References } \\
\hline & $\mathrm{IL}-1 \beta$ & IL-2 & IL-4 & IL-6 & IL-8 & IL-10 & IL-12 & IFN- $\gamma$ & TNF- $\alpha$ & TGF- $\beta$ & \\
\hline \multicolumn{12}{|c|}{ AFFECTIVE DISORDERS } \\
\hline Depression & $\leftrightarrow$ & $\leftrightarrow$ & $\leftrightarrow$ & $\uparrow$ & $\leftrightarrow$ & $\uparrow$ & $\uparrow$ & $\downarrow$ & $\uparrow$ & $\leftrightarrow$ & Köhler et al. (2) \\
\hline BAD & $\uparrow$ & $\leftrightarrow$ & $\uparrow$ & $\leftrightarrow$ & $\leftrightarrow$ & $\uparrow$ & & $\leftrightarrow$ & $\uparrow$ & & Modabbernia et al. (39) \\
\hline - Manic & & & & $\uparrow$ & & $\leftrightarrow$ & & & $\uparrow$ & & Goldsmith et al. (38) \\
\hline - Depressed & & & $\uparrow$ & $\leftrightarrow$ & & $\leftrightarrow$ & & & $\leftrightarrow$ & & Goldsmith et al. (38) \\
\hline - Euthymic & & $\uparrow$ & & & & $\uparrow$ & & $\uparrow$ & $\uparrow$ & & Goldsmith et al. (38) \\
\hline \multicolumn{12}{|c|}{ SCHIZOPHRENIA } \\
\hline First episode & $\uparrow$ & $\leftrightarrow$ & & $\uparrow$ & $\uparrow$ & $\uparrow$ & $\uparrow$ & $\uparrow$ & & $\uparrow$ & Goldsmith et al. (38) \\
\hline Acute relapse & $\uparrow$ & $\leftrightarrow$ & $\downarrow$ & $\uparrow$ & $\uparrow$ & $\downarrow$ & $\uparrow$ & $\uparrow$ & $\uparrow$ & $\uparrow$ & Goldsmith et al. (38) \\
\hline \multicolumn{12}{|c|}{ TRAUMA- AND STRESSOR-RELATED DISORDERS } \\
\hline PTSD & $\uparrow$ & $\leftrightarrow$ & $\leftrightarrow$ & $\uparrow$ & $\leftrightarrow$ & $\leftrightarrow$ & & $\uparrow$ & $\leftrightarrow$ & & Passos et al. (36) \\
\hline \multicolumn{12}{|c|}{ OBSESSIVE-COMPULSIVE DISORDERS } \\
\hline OCD & $\downarrow$ & & & $\leftrightarrow$ & & & & & $\leftrightarrow$ & & Gray and Bloch (40) \\
\hline \multicolumn{12}{|c|}{ EATING DISORDERS } \\
\hline AN & $\leftrightarrow$ & & & $\uparrow$ & & & & & $\uparrow$ & $\leftrightarrow$ & Dalton et al. (37) \\
\hline $\mathrm{BN}$ & & & & $\leftrightarrow$ & & & & & $\leftrightarrow$ & & Dalton et al. (37) \\
\hline
\end{tabular}

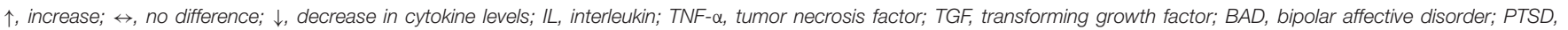
post-traumatic stress disorder; OCD, obsessive-compulsive disorder; AN, anorexia nervosa; BN, bulimia nervosa.

\section{Cytokine Effects}

One cytokine can act on multiple cell types and have different effects on these cells (48). For example, IL-4 can induce activation of $B$ lymphocytes but inhibit $T$ helper type $1\left(\mathrm{~T}_{\mathrm{H}} 1\right)$ cells (49). It can further lead to differentiation of cytotoxic $\mathrm{T}$ cell precursors and proliferation in mast cells (50). Regarding TNF- $\alpha$, all cell types of the body express TNF- $\alpha$ receptor type 1 (TNF-R1) (51). When bound to TNF- $\alpha$, these TNF receptors transduce growth regulatory signals. TNF- $\alpha$ is able to initiate apoptosis in some cells causing DNA fragmentation and cytolysis, but also cell growth and differentiation in others. Whether TNF- $\alpha$ induces cell differentiation or apoptosis depends on the signaling pathway activated within the cell. The NF- $\mathrm{B}$ signaling pathway will lead to cell differentiation, whereas cells in which caspases are activated are more likely to undergo apoptosis in response to TNF- $\alpha$ (24). IL-10 can be inhibitory to macrophages and $\mathrm{T}_{\mathrm{H}} 1$ cells, yet activating for $\mathrm{T}_{\mathrm{H}} 2$ cells and $\mathrm{B}$ cells and can thus be immunosuppressive as well as immunostimulatory (52). The phenomenon that one cytokine can have diverse effects on different cells is called pleiotropy.

Cytokine signaling shows redundancy, because two or more cytokines can have a similar function. IL- 2 and IL- 4 both enhance T cell proliferation (53). All three IFNs, IFN- $\alpha$, IFN- $\beta$, and IFN$\gamma$, increase the activity of natural killer lymphocytes and stimulate the synthesis of arachidonic acid products (54). IFN- $\gamma$, IL-2, and TNF- $\alpha$ promote cellular immunity and the activation of cytotoxic cell contacts (55).

Another typical phenomenon in cytokine signaling is synergy which is a strong combined effect of 2 cytokines when acting together e.g., IL-3 and IL-4 amplify each other to induce growth, differentiation, and activation of mast cells in a synergistic way
(47). Cytokines can also antagonize each other's effects. For example, IL-12 which activates $\mathrm{T}_{\mathrm{H}} 1$ cells can be blocked by IL-4 (56-58). Another example of cytokine antagonism is that cytokines of the IL-1 superfamily can antagonize IL-18 effects (59). Additionally, cytokine cascades play a significant role in cytokine signaling which means that an activation of one cytokine produced by one cell type induces cytokine production by other cell types. For example, IL-4 induces the expression of IL-3, IL-5, and IL-13 (60).

\section{CYTOKINES WITHIN THE IMMUNE SYSTEM}

\section{The Role of Cytokines Possibly Relevant for Research in Affective Disorders Within the Immune System}

Many cytokines with vital roles for the regulation of the immune system have been investigated in affective disorders. Examples of such immunologically important cytokines measured in the serum of patients with depression are IL-1, IL-2, IL-4, IL-5, IL-6, IL-10, IL-12, IL-13, IL-17, IFN- $\alpha$, IFN- $\gamma$, TNF$\alpha$, and transforming growth factor (TGF) $\beta$ ( $\beta$, 33, 61-64). Other cytokines with immunologically important functions are IL-21 (65) and IL-22 (66), though both of which have only recently gained the interest of the depression research field. IL-21 has been studied regarding its role in response to treatment with the antipsychotic aripiprazole (67), which can also be used as an augmentation strategy in treatmentresistant depression (68), and IL-22 production has been shown to increase during exposure to antidepressants like citalopram or mirtazapine (69). 
Figure 1 is an attempt to create a simplified schematic figure that depicts the role of these cytokines within the immune system. This figure tries to bring some order to the different cytokines measured in psychiatric research, which are often discussed without explaining the immunological context of these molecules.

The immune system is divided into the innate and the adaptive immune response. The innate immune system can fight pathogens without a previous contact with them. The tasks of the innate immune system are performed by astrocytes (A), microglia (MG), dendritic cells (DC), granulocytes $(\mathrm{G})$, natural killer cells (NKZ), and macrophages (M $\Phi)$ (upper part of Figure 1). These cells modulate the further immune response by the production of cytokines like IL-1, IL-4, IL-6, IL-12, and TNF- $\alpha$.

To understand the adaptive immune system, we will assume two different scenarios that lead either to specific cytotoxic cell contacts or the production of specific antibodies (see left middle and lower part of Figure 1). One scenario within the immune system could be a viral infection. This can lead to the production of IL-12 by cells of the innate immune system which activates $\mathrm{T}_{\mathrm{H}} 1$ cells. Consequently, they produce IFN- $\gamma$, IL-2, and TNF- $\alpha$ which, in turn, activate cytotoxic T cells. Cytotoxic T cells can destroy the virus-infected cells (70). Another potential scenario would be that cells of the innate immune system release IL4 following a bacterial infection. IL- 4 stimulates $\mathrm{T}_{\mathrm{H}} 2$ cells. $\mathrm{T}_{\mathrm{H}} 2$ cells, in turn, will produce IL-4, IL-5 and IL-13 and thereby induce the production of antibodies which can help to mark and eliminate the pathogens (70).

If the cells of the innate immune system produce IL1 , IL- 6 or TNF- $\alpha$, the consequence is an activation of the so-called $\mathrm{T}$ helper $17\left(\mathrm{~T}_{\mathrm{H}} 17\right)$ cells which produce cytokines like IL-17, IL-21, and IL-22. Together with IL-1, IL-6, IL8 , TNF- $\alpha$ and IFN- $\alpha$, IL-17, IL-21, and IL-22 are cytokines which promote inflammation. Therefore, they are called proinflammatory cytokines $(71,72)$. Inflammatory processes, in turn, are bidirectionally linked to cytotoxic and antibody-driven mechanisms. An anti-inflammatory effect, in contrast, occurs when naïve T helper $\left(\mathrm{T}_{\mathrm{H}} 0\right)$ cells produce TGF- $\beta$. TGF- $\beta$ activates regulatory $\mathrm{T}\left(\mathrm{T}_{\text {reg }}\right)$ cells which produce IL-10 and further TGF- $\beta$. These cytokines have an anti-inflammatory effect (73) (see right middle and lower part of Figure 1).

\section{Types of Cytokines According to Their Immunological Function}

With this knowledge, we can distinguish between four categories of cytokines which are often talked about in the psychoimmunological literature:

- $\mathrm{T}_{\mathrm{H}} 1$ cytokines (IL-2, IL-12, IFN- $\gamma$ ) which fuel the $\mathrm{T}_{\mathrm{H}} 1$ branch of the immune system and lead to cytotoxic cell contacts.

- $\mathrm{T}_{\mathrm{H}} 2$ cytokines (IL-4, IL-5, IL-13) which stimulate the $\mathrm{T}_{\mathrm{H}} 2$ branch of the immune system and induce the production of antibodies.

- Pro-inflammatory cytokines (IL-1, IL-6, IL-8, IL-17, IL-21, IL-22, IFN- $\alpha$, TNF- $\alpha$ ) which promote inflammation.
- Anti-inflammatory cytokines (IL-10, TGF- $\beta$ ) which are influenced by regulatory $\mathrm{T}$ cells and prevent inflammatory processes from escalating.

Even though these categories are often referred to in the psychoimmunological literature, these are neither distinct nor generally accepted categories for the classification of cytokines. However, this functional classification might help to understand recent research papers on pro-inflammatory, anti-inflammatory, $\mathrm{T}_{\mathrm{H}} 1$ and $\mathrm{T}_{\mathrm{H}} 2$ cytokines in depression [e.g., (74-77)]. One must also take into account that cytokines can have different effects on different cells and thus may have pro- but also anti-inflammatory properties. Moreover, cytokines produced by certain $\mathrm{T}$ helper cells, for example IL-13 which is produced by $\mathrm{T}_{\mathrm{H}} 2$ cells, have antiinflammatory properties (78). Thus, they can be $\mathrm{T}_{\mathrm{H}} 2$ as well as anti-inflammatory cytokines. Even though IFN- $\alpha$ has been listed in this figure as a pro-inflammatory cytokine, IFN- $\alpha$ also has several anti-inflammatory properties (79).

\section{THE INFLUENCE OF CYTOKINES ON THE BRAIN}

\section{How Cytokines Enter the Brain}

As previously mentioned, cytokines can be produced by neurons, astrocytes and microglia within the brain (see Figure 1). Additionally, peripherally produced cytokines can access and affect the brain through three pathways: humoral, neural, and cellular (31).

The humoral pathway describes when cytokines access the brain through leaky sections of the blood-brain barrier such as the choroid plexus and the circumventricular organs. The neural pathway involves the stimulation of primary afferent nerve fibers in the vagus nerve by pro-inflammatory cytokines. The cellular pathway describes how pro-inflammatory cytokines stimulate microglia to produce monocyte chemoattractant protein-1 (MCP-1), which subsequently recruits monocytes to the meninges and brain parenchyma $(31,80)$.

\section{Influence on Neurotransmitter Metabolism and Signaling}

Given that peripheral production of cytokines has been associated with depression $(2,81)$, and that peripherally produced cytokines can influence the central nervous system (CNS), the impact of cytokines on neurotransmitters such as serotonin has been studied extensively. For example, animal (82-84) and clinical $(85,86)$ studies have found an altered metabolism of serotonin resulting from cytokine exposure. Cytokines can decrease serotonin synthesis by activating the enzyme indoleamine 2,3 dioxygenase (IDO) which breaks down tryptophan, the amino acid precursor of serotonin, to kynurenin (KYN) instead of metabolizing tryptophan to serotonin. This process of serotonin depletion has been postulated to be associated with major depression $(87,88)$. Cytokines also influence the synthesis of monoamines through disruption of tetrahydrobiopterin, an essential enzyme co-factor to hydroxylases involved in monoamine synthesis. Furthermore, they can modulate serotonin signaling 


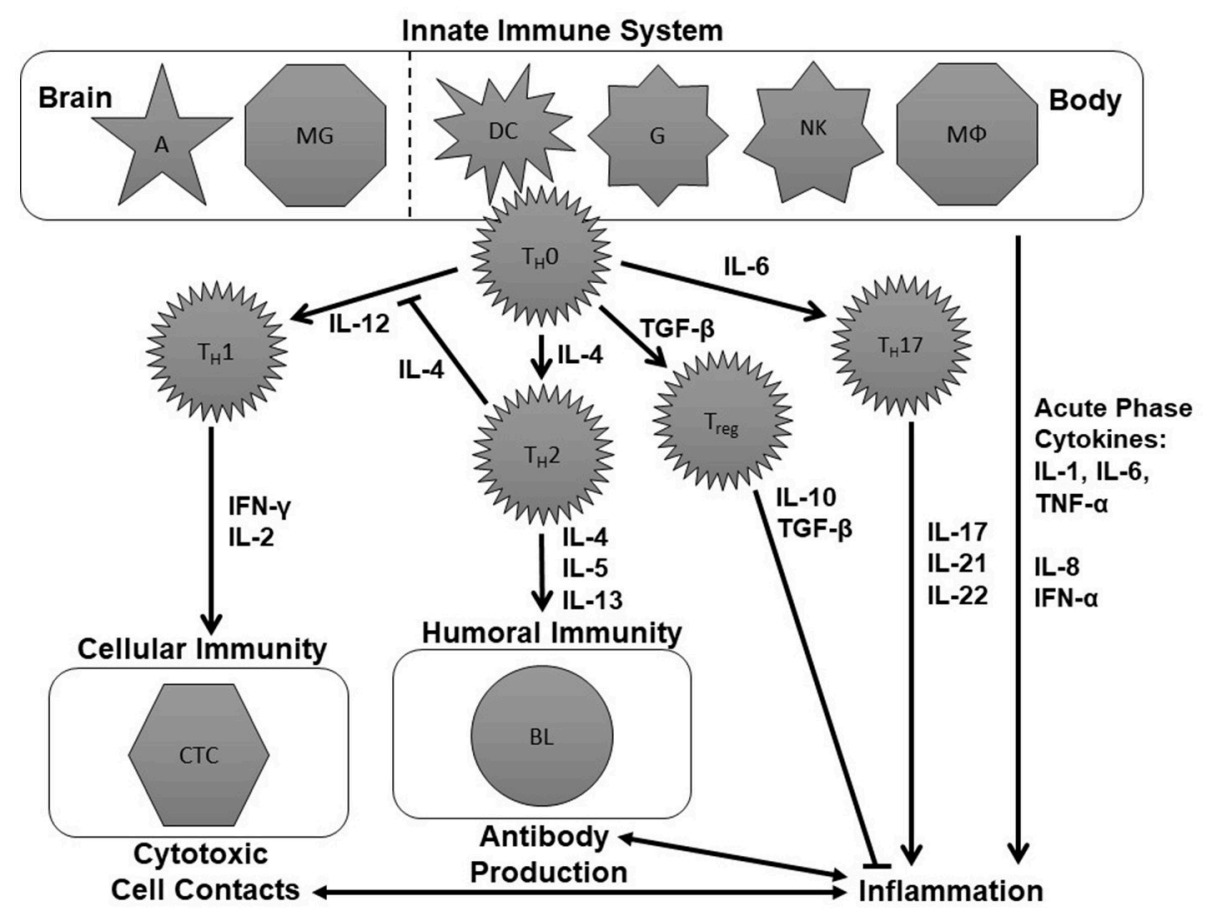

FIGURE 1 | Schematic figure of the immune system. This is an over-simplified representation of the immune system, deliberately so, to focus on aspects that have already been investigated in the immune-psychiatry literature. The tasks of the innate immune system are performed by astrocytes (A), microglia (MG), dendritic cells $(D C)$, naïve granulocytes $(G)$, natural killer cells $(N K)$, and macrophages $(M \Phi)$. These cells modulate the further immune response involving naïve $T$-helper $\left(T_{H} 0\right)$, $T$ helper $1\left(T_{H} 1\right)$, T helper $2\left(T_{H} 2\right)$, and $T$ helper $17\left(T_{H} 17\right)$ cells, regulatory $T$ cells $\left(T_{\text {reg }}\right)$ as well as cytotoxic $T$ cells and $B$ lymphocytes (BL) by the production of cytokines including interleukins (IL), interferons (IFN), tumor necrosis factor- $\alpha$ (TNF- $\alpha$ ), and transforming growth factor- $\beta$ (TGF- $\beta$ ). For further details see text.

by increasing the expression and function of monoamine transporters which perform the re-uptake of synaptic serotonin (89-92). Moreover, pro-inflammatory cytokines can affect the release of neurotransmitters (93). For example, glutamate release by astrocytes has been shown to be affected by cytokines, potentially leading to excitotoxicity $(94,95)$. In addition, proinflammatory cytokines have been implicated in the stimulation of N-methyl-D-aspartate (NMDA) receptors, and the inhibition of $\gamma$-aminobutyric acid (GABA) and acetylcholine signaling (96).

Furthermore, cytokines are involved in autoimmunity, including the production of autoantibodies. For example, autoantibodies against dopamine- 2 receptors have been found to contribute to the development of pediatric neuropsychiatric disorders associated with streptococcal infection and subjects with Tourette's syndrome (97). Autoantibodies against serotonergic and cholinergic receptors are thought to induce depressive syndromes (98).

\section{Influence on Neuroendocrine Signaling}

Cytokines can also affect neuroendocrine function by increasing hypothalamic-pituitary-adrenal (HPA) axis activity. Acute cytokine administration has been shown to increase corticotropin-releasing hormone $(\mathrm{CRH})$, adrenocorticotropic hormone $(\mathrm{ACTH})$, and cortisol release, all of which have been found to be elevated in patients with major depression (99-101). In contrast, chronic cytokine administration is associated with a flattening of the diurnal cortisol curve, which has been linked to adverse behavioral effects and poor outcomes in several illnesses such as cardiovascular disorders and cancer (102-104). Inflammatory cytokines are hypothesized to exert these effects through the disruption of the cortisol receptor's (glucocorticoid receptor) expression and function (101).

\section{Influence on Neurogenesis and Autoimmune Destruction of Nerve Cells}

Neurogenesis is another aspect of brain activity influenced by cytokines. As mentioned previously, certain pro-inflammatory cytokines stimulate glutamate release by astrocytes. Glutamate can have a detrimental effect on neurogenesis by binding to extrasynaptic NMDA receptors, leading to a decrease in brain-derived neurotrophic factor (BDNF), which is pivotal for neurogenesis (105). Additionally, an activation of TNF- $\alpha$ signaling has been suggested to contribute to the destruction of hypocretin neurons in patients with narcolepsy $(23,106)$.

\section{Influence on Specific Brain Regions}

Cytokines' effects on specific brain regions have been demonstrated through imaging techniques. Among those brain regions influenced by cytokines are the basal ganglia, which are involved in motor activity and motivation, the dorsal anterior cingulate cortex (ACC), which is a central area for the generation of anxiety, and the subgenual ACC, which has 
been reported to be involved in the development of depression $(107,108)$.

Positron emission tomography (PET) studies have revealed that the application of IFN- $\alpha$ leads to increases in basal ganglia glucose metabolism $(109,110)$. This is of specific interest for cytokine research in depression because depression and fatigue are the main side effects of treatment with IFN$\alpha(111,112)$. IFN- $\alpha$ has also been implicated in increased ACC activation as evidenced by fMRI studies (113, 114), and such ACC activation is associated with increased anxiety, arousal, obsessive-compulsive disorder and bipolar affective disorder (108).

\section{CYTOKINE ALTERATIONS IN DEPRESSION AND OTHER PSYCHIATRIC DISORDERS}

\section{Cytokine Alterations in Patients With Affective Disorders}

Regarding the main cytokines examined in affective disorders, meta-analytic research has revealed that patients with depression have elevated serum or plasma concentrations of IL-6, IL-10, IL-12, IL-13, IL-18, TNF- $\alpha$, and its receptor soluble TNFR2 compared to healthy controls, whereas IFN- $\gamma$ levels are lower in patients with depression than healthy controls $(2,33,61-$ 63). Similarly, production of IL-6, IL-10, and TNF- $\alpha$ levels have been shown to be increased in animal models for depression using acute or restraint stress, whereas IFN- $\gamma$ production was significantly decreased by restraint stress in rats (115). In bipolar disorder, Munkholm et al. (116) found significantly higher serum or plasma levels of TNF- $\alpha$, its receptor soluble TNFR1 and IL4. However, these cytokines have not been found to be elevated by all studies in patients with depression and bipolar patients $(2,116)$.

\section{Cytokine Alterations in Patients With Psychiatric Disorders in General}

The aforementioned cytokine alterations in affective disorders are not specific to major depression or bipolar disorder. For example, elevated levels of TNF- $\alpha$ have also been found in PTSD studies (34), in patients with anorexia nervosa (37) and in patients with acute relapse of schizophrenia $(31,38)$. An overview of meta-analytic studies on cytokine research in selected psychiatric disorders is shown in Table 2.

If we take a closer look at the raw data of specific studies, we see high variation in cytokine levels within groups of patients or healthy controls. For example, in a paper published by Schmidt et al. (33), mean TNF- $\alpha$ serum concentrations of depressed patients were $50.35 \mathrm{pg} / \mathrm{ml}$ with a standard deviation of $78.01 \mathrm{pg} / \mathrm{ml}$, whereas mean TNF- $\alpha$ levels of healthy controls were $33.80 \pm 46.17 \mathrm{pg} / \mathrm{ml}$. This range indicates that, despite the significant difference between the means of both groups, depressed participants and healthy controls did not have distinct TNF- $\alpha$ levels, but rather overlapping ranges of TNF- $\alpha$ levels.

\section{POSSIBLE REASONS FOR CYTOKINE ALTERATIONS}

\section{Direction of Causality}

Even though there is considerable evidence for an involvement of cytokines in the pathophysiology of many psychiatric disorders, the directionality of this relationship has not yet been elucidated with certainty. However, evidence is increasing that inflammation and specifically cytokine signaling play a role in the pathophysiology of psychiatric disorders. Such evidence derives from genetic studies, long-term cohort studies and from studies investigating people with inflammatory diseases. Nevertheless, cytokine changes might also be the consequence of a psychiatric disorder, for example they can be a consequence of treatment with psychopharmacological agents or of weight changes that appear during acute episodes of the disorder or during recovery (117).

There is considerable evidence that genetic risk factors for psychiatric disorders are closely related to cytokines or other functions of the immune system. Genome-wide association studies (GWAS) have identified immune pathway genes that significantly contribute to the risk of psychiatric disorders (118). Psychiatrically relevant genes include, for example, those in the human leukocyte antigen (HLA) gene complex or rare copy number variants important for immune function (119).

The results of the Whitehall II cohort study in which British civil workers were monitored for CRP, IL-6 and cognitive symptoms of depression from 1991 to 2004 (baseline and followup) suggest that the inflammatory markers measured predicted symptoms of depression at follow-up, but not the other way around (120).

Studies have shown that CNS inflammation caused by infection can lead to the development of psychiatric symptoms (121) or full-blown syndromes such as depressive or manic episodes (122). However, it must be mentioned that the observation that inflammatory diseases can lead to psychiatric disorders, such as depression, is not an achievement of recent decades of research: a meta-analytic scientific approach to such observations had already been published by Emil Kraepelin in 1881 and 1882 (123).

\section{Risk Factors for Psychiatric Disorders Associated With Changes in Cytokine Production}

If we consider the risk factors of depressive disorder, we will find familial and developmental risk factors, factors related to the natural and social environment, psychological and medical risk factors, as well as molecular factors related to genetics, epigenetics, gene expression and the brain, and the endocrine and the immune system (124-126). Table 3 provides evidence from the scientific literature that all of these risk factors for depression have been shown or suggested to be associated with alterations in cytokine production or cytokine signaling. Thus, the cytokine system seems to be involved in almost all possible predisposing or precipitating risk factors for depression that contribute to the presentation of the disorder. A risk factor 
TABLE 3 | Possible risk factors for the development of depression which have also been linked to alterations in cytokine production and signaling.

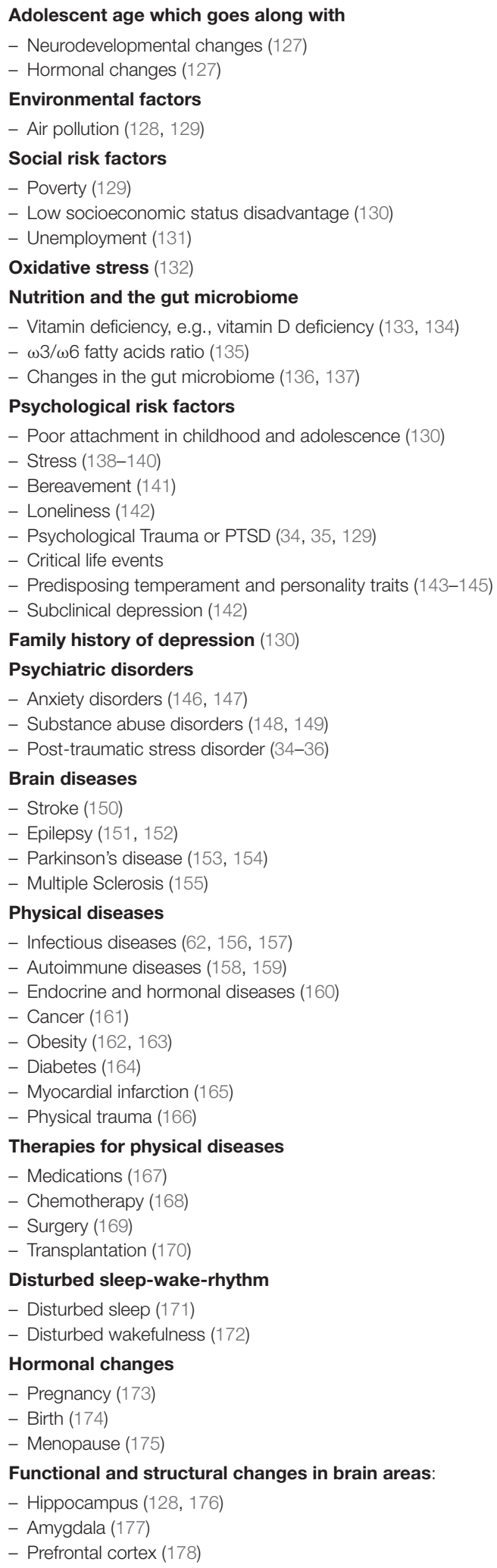

TABLE 3 | Continued

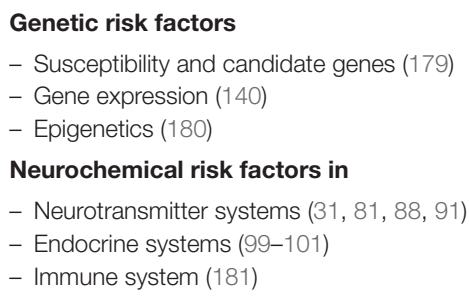

The cited literature refers to articles that report, review, or hypothesize an association of the risk factor in question with changes in cytokine production or cytokine signaling.

like acute or chronic stress could, for example, lead to an increased production of pro-inflammatory cytokines $(115,138-$ 140 ), and these cytokines could then enter the brain (31) and lead to changes in neurotransmitter systems involved in the development of depression, such as the serotonin system $(82,83$, $85,86,182)$.

\section{Confounding Factors}

There are a number of confounding factors that influence cytokine serum or plasma levels. Important confounders include aging, body weight, smoking, excessive alcohol consumption, and medication (183).

Normal aging is marked by chronic low-level inflammation characterized by over-expression of circulating pro-inflammatory factors $(184,185)$. Chronic inflammation with increased circulating levels of cytokines is also characteristic of obesity $(162,186,187)$. Adipose tissue is known to accumulate and activate macrophages and lymphocytes which secrete inflammatory factors $(186,187)$. Both the obese and the elderly exhibit behavioral symptoms such as depression and cognitive dysfunction at an increased rate compared to the general population. Several studies have shown that the elevated levels of inflammation may contribute to the prevalence of neuropsychiatric disorders in these populations (188-192).

Smoking (193), excessive alcohol consumption (148), and drug abuse (149) have been associated with inflammatory changes in the immune system, as reflected by an increase of pro-inflammatory cytokines. Also, psychopharmacological medication, specifically those agents which lead to weight gain, have been reported to activate cytokine production $(117,194)$. It is not clear, however, whether the activation of cytokines by psychotropic drugs is the cause or a consequence of weight gain in the course of psychopharmacological treatment. As growing white adipose tissue becomes infiltrated by macrophages, this fatty tissue could be a major source of pro-inflammatory cytokines in the context of increasing body weight during psychopharmacological treatment (195).

One has to keep in mind, however, that alcohol misuse (148), obesity (163) are not only confounding factors, but also risk factors for the development of depression. Therefore, they should not be dismissed as mere confounders whilst performing research on causative factors of affective disorders. 


\section{Physical Disorders and Their Therapy}

Many physical disorders have been reported to increase the risk for developing a depressive disorder (125) and to activate the production of pro-inflammatory cytokines. Examples are autoimmune and infectious diseases (156-159), endocrine and hormonal diseases (160), cancer (161), diabetes (164), myocardial infarction $(165,196)$, and physical trauma (166). The treatment of physical disorders, e.g., interferon-based or virostatic treatments for hepatitis C $(167,197)$, chemotherapy for the treatment of cancer (168), surgery (169) or transplantation (170), can lead to additional cytokine release.

\section{Food and the Microbiome}

Vitamin deficiency, e.g., vitamin D deficiency, has also been shown to increase pro-inflammatory cytokine production and to lead to depressive symptoms $(133,134)$. Another example of how food can influence the immune system is the antiinflammatory effect of $\omega 3$ fatty acids, which can reduce the production of IL- $1 \beta$, IL- 6 , and TNF- $\alpha$. $\omega 6$ fatty acids, in contrast, promote the production of these pro-inflammatory cytokines. Therefore, foods with a high ratio of $\omega 3 / \omega 6$ fatty acids can dampen inflammatory processes and thus potentially prevent or ameliorate depressive symptoms (135).

There is an increasing body of evidence for an influence of the gut microbiome on cytokine signaling and on the development of depression. Gut microbes have, for example, been found to be capable of producing certain neurotransmitters and of influencing the central neurochemistry of the brain and thus human behavior (136). Molecules produced by microbiota, e.g. LPS, can induce cytokine production (198), and lead to depressive symptoms (199). The microbiome is linked to food intake and diet. However, the relationship is complex (200).

\section{CYTOKINE CHANGES DURING TREATMENT FOR DEPRESSION}

\section{The Influence of Antidepressants on Cytokine Production}

Some studies have investigated whether cytokine serum or plasma concentrations in vivo change during treatment with antidepressants. However, the results are conflicting. For example, in a study by Kraus et al. (201), TNF- $\alpha$ levels were measured longitudinally during treatment with mirtazapine or venlafaxine. Whereas, mirtazapine induced a significant increase in the plasma levels of TNF- $\alpha$ and both soluble TNF receptors, venlafaxine did not alter plasma levels of TNF- $\alpha$, or soluble TNF receptors significantly (201). These findings that mirtazapine increases circulating TNF- $\alpha$ levels were supported by Kast et al. (202). In contrast, however, Gupta et al. (203) found that successful treatment with mirtazapine led to a decrease in serum TNF- $\alpha$ levels. There is currently not enough scientific literature available to draw firm conclusions about the influence of certain antidepressants on plasma or serum levels of cytokines in vivo. However, a recent meta-analysis which included data derived from 45 longitudinal studies and more than 1,500 patients found that antidepressant treatment, overall, decreases peripheral levels of IL-6, IL-10, and TNF- $\alpha$ (2).
Certain subgroups of depressed patients, for example those with psychotic depression, are usually treated with a combination of an antidepressant and an antipsychotic drug (204). Among antipsychotics, it has been shown that those with the highest risk of weight gain, for example clozapine and olanzapine (117), lead to a significant increase in pro-inflammatory cytokine levels in the blood (194). For patients with recurrent episodes of depression or bipolar depression, the treatment with mood stabilizers is recommended (205). Some of these mood stabilizers, for example lithium and carbamazepine, have also been shown to lead to weight gain as well as an increase in pro-inflammatory cytokine levels (206).

The in vitro literature on antidepressants suggest that some antidepressants, such as clomipramine and fluoxetine, decrease IL-6, IFN- $\gamma$, and TNF- $\alpha$, whilst others like mirtazapine and venlafaxine tend to increase their levels (207). From these results, one is tempted to draw the conclusion that serotonin reuptake inhibitors (SSRIs) or serotonin and noradrenalin reuptake inhibitors (SNRI) generally decrease IL-6, IFN- $\gamma$, and TNF- $\alpha$ levels. However, the SSRI citalopram increased the production of IL-1 $\beta$, IL-6, and TNF- $\alpha$ in another in vitro study (69). What in vitro studies clearly show, however, is that antidepressants (69), antipsychotics (208) and mood stabilizers (209) have a direct influence on cytokine production within the blood.

\section{Cytokine Levels and Antidepressant Response}

Occasionally, studies have reported that baseline levels of certain cytokines or cytokine changes during treatment were associated with antidepressant treatment response during treatment with specific antidepressants or a certain combination of antidepressants. For example, Jha et al. (210) found that higher baseline levels of IL-17 were associated with greater symptomatic reduction in depressed patients treated with a bupropion-SSRI combination. However, the research in this area is sparse, and therefore, it is too early to draw far reaching conclusions from such observations. Regarding changes of cytokine levels during antidepressant treatment, the aforementioned recent meta-analysis of Köhler et al. (2) did not provide evidence that reductions in peripheral inflammation are associated with antidepressant treatment response.

\section{Cytokine Levels and Psychotherapy}

Not only antidepressants, but also psychotherapy has been reported to be associated with cytokine changes. For example, Del Grande da Silva et al. (211) reported a clinical study showing that successful brief psychodynamic psychotherapy leads to a reduction of pro-inflammatory cytokine serum levels.

\section{DISCUSSION}

\section{Historical Considerations}

The close relationship between inflammatory processes and psychiatric symptoms has been scientifically investigated since the 19th century (123). Shortly after the discovery of the first cytokine, IFN- $\alpha$ (12), it became clear that this cytokine was able to influence immunological processes in the brain 
even when peripherally administered $(17,18)$ and that it can be produced by cells within the brain (18). Therefore, even though cytokines were discovered as messenger molecules with important immunological functions, it quickly became clear that they also play an important role within and for the brain.

\section{Difficulties in Interpreting the Results of Cytokine Research}

During the 1970s it became clear that immune cells are not the only cells that release cytokines (19). For example, TNF- $\alpha$ can be produced by white blood cells, the endothelium, fat cells and other cells (46). Therefore, if we measure a specific cytokine like TNF- $\alpha$ in the serum or plasma, it is unclear from which cells or which organ it is derived and where this cytokine will exert its effect, as one cytokine can have different effects on different cell types (10).

As cytokine signaling often shows redundancy (53-55), synergy (47), antagonistic effects (56-59) or signaling cascades (60), it seems advisable to take all cytokines that work together or against each other into account and thus measure a whole range instead of a single cytokine.

\section{Cytokines as Potential Biomarkers of Depression}

As peripheral levels of IL-6, IL-10, IL-12, IL13, and TNF- $\alpha$ have been shown to be significantly elevated and IFN- $\gamma$ plasma concentrations significantly lower in patients with depression compared to healthy controls in meta-analytic research (2), one could think that cytokines qualify as a biomarker of depression. This perspective could be supported by further meta-analytic findings that antidepressant treatment decreases peripheral levels of IL-6, IL-10, and TNF- $\alpha$ (2). However, one has to take into account that these are results comparing means of groups. There is huge overlap of the distributions of cytokine levels of depressed patients and healthy controls, and additionally, the meta-analytic research of Köhler et al. (2) did not provide evidence that reductions in peripheral inflammation are associated with antidepressant treatment response. Thus, the mentioned group effects may not be relevant on an individual level. Additionally, the described effects of antidepressants on certain cytokines may be a mere pharmacological effect of these medications on immune cells that is not necessarily related to the depressive syndrome, as it has been shown that antidepressants (69), antipsychotics (208), and mood stabilizers (209) influence cytokine production directly.

\section{Challenges in Regard to the Current Diagnostic Criteria}

People with depression exhibit heterogeneous sets of symptoms. Thus, it may be sensible to define subgroups of patients with depression with more homogenous psychopathology. It might well be that within such a subgroup, cytokines are of greater value as an individualized biomarker of disease severity and antidepressant response. However, an alternative perspective may also be worth considering: cytokines could be associated with depressive syndromes independent of the psychiatric diagnosis. For example, patients with schizophrenia can also suffer from depressive symptoms (212). Therefore, cytokine levels may not only be associated with a diagnostic category, but with transdiagnostic depressive symptoms. This might be a reason for limited specificity of cytokines as biomarkers for a certain psychiatric diagnosis, because the mentioned cytokine levels are not only elevated in depression, but also in other psychiatric disorders (see Table 2). Moreover, a number of environmental, social, psychological and medical factors (see Table 3) are also associated with cytokine changes. Therefore, cytokines may currently not be considered as specific biomarkers for depression.

\section{Future Perspectives on Cytokines as Biomarkers for Depression}

There are many immunologically important cytokines like IL-21 (65) and IL-22 (66) which have not been extensively researched in psychiatric samples yet, even though the first preliminary studies have revealed promising results $(67,69)$. Cytokine levels are often researched and interpreted in isolation from their origin in terms of the specific cell type and the particular tissue they are originating from, even though changes in specific cytokineproducing immune cells like $\mathrm{T}_{\text {reg }}$ cells have been reported in depression (213) and during antidepressant therapy (214). Additionally, their receptors and their target tissue have been neglected in psychiatric research, despite considerations that modulation of cytokine receptors might be a promising future antidepressant strategy (215).

At this point, we would like to mention that there are only few studies available that measured cytokine concentrations in the cerebrospinal fluid [e.g., (216)], even though one would assume that cytokine concentrations in the cerebrospinal fluid might better reflect cytokine signaling in the brain than cytokine levels in the serum or plasma.

Taken together, including novel cytokines, cells and tissues of their origin, their receptors and target tissues in future scientific and clinical projects might help to fill the gaps in our knowledge in immunological biomarker research.

\section{Future Perspectives on Cytokines as a Therapeutic Target for Antidepressant Treatment}

Animal experiments have shown that cytokine blockers like TNF$\alpha$ blockers can be effective in the treatment of depression-like behavior (217). However, attempts to try cytokine blockers in people with depression did not show striking success (218). Furthermore, designer monoclonal antibodies to bind directly to the cytokine and soluble cytokine receptors are currently being developed which will hopefully have less severe side effects than those currently available.

\section{AUTHOR CONTRIBUTIONS}

$\mathrm{HH}, \mathrm{OP}, \mathrm{NL}$, and $\mathrm{BD}$ conducted the literature search. $\mathrm{HH}$ and MI drafted the manuscript. All authors were involved in drafting, critiquing and approving of the manuscript, and accept responsibility for the accuracy, and integrity of this work. The authors were the only individuals who contributed to this publication. 


\section{FUNDING}

BD is supported by a studentship awarded by the Department of Psychological Medicine, King's College London (KCL) and the Institute of Psychiatry, Psychology and Neuroscience

\section{REFERENCES}

1. Köhler CA, Freitas TH, Maes M, de Andrade NQ, Liu CS, Fernandes BS, et al. Peripheral cytokine and chemokine alterations in depression: a meta-analysis of 82 studies. Acta Psychiatr Scand. (2017) 135:373-87. doi: 10.1111 /acps. 12698

2. Köhler CA, Freitas TH, Stubbs B, Maes M, Solmi M, Veronese $\mathrm{N}$, et al. Peripheral alterations in cytokine and chemokine levels after antidepressant drug treatment for major depressive disorder: systematic review and meta-analysis. Mol Neurobiol. (2017) 55:4195-206. doi: 10.1007/s12035-017-0632-1

3. Burgey C, Kern WV, Römer W, Sakinc T, Rieg S. The innate defense antimicrobial peptides $\mathrm{hBD} 3$ and RNase7 are induced in human umbilical vein endothelial cells by classical inflammatory cytokines but not Th17 cytokines. Microbes Infect. (2015) 17:353-9. doi: 10.1016/j.micinf.2015.01.005

4. Enzerink A, Vaheri A. Fibroblast activation in vascular inflammation. J Thromb Haemost. (2011) 9:619-26. doi: 10.1111/j.1538-7836.2011.04209.x

5. Tsuruda T, Imamura T, Hatakeyama K, Asada Y, Kitamura K. Stromal cell biology. Circ J. (2010) 74:1042-50. doi: 10.1253/circj.cj-10-0024

6. Barbierato M, Facci L, Argentini C, Marinelli C, Skaper S, Giusti P. Astrocyte-microglia cooperation in the expression of a pro-inflammatory phenotype. CNS Neurol Disord Drug Targets (2013) 12:608-18. doi: 10.2174/18715273113129990064

7. Lackie J, O'Callaghan CA. A Dictionary of Biomedicine. (2010) OUP Oxford

8. Stedman TL. Stedman's Medical Dictionary (2006). Philadelphia, PA: Wolters Kluwer Health/Lippincott Williams \& Wilkins

9. Lodish H, Berk A, Zipursky SL, Matsudaira P, Baltimore D, Darnell J. Molecular Cell Biology 4th ed. New York, NY: W. H. Freeman (2000).

10. Tracey KJ, Cerami A. Tumor necrosis factor and regulation of metabolism in infection: role of systemic versus tissue levels. Exp Biol Med. (1992) 200:233-9. doi: 10.3181/00379727-200-43426

11. Esler M, Jennings G, Lambert G, Meredith I, Horne M, Eisenhofer G. Overflow of catecholamine neurotransmitters to the circulation: source, fate, and functions. Physiol Rev. (1990) 70:963-85. doi: 10.1152/physrev.1990.70.4.963

12. Isaacs A, Lindenmann J. Virus interference. I. the interferon. Proc Royal Soc B Biol Sci. (1957) 147:258-67. doi: 10.1098/rspb.1957.0048

13. Wheelock EF. Interferon-like virus-inhibitor induced in human leukocytes by phytohemagglutinin. Science (1965) 149:310-1. doi: $10.1126 /$ science.149.3681.310

14. Bloom BR, Bennett B. mechanism of a reaction in vitro associated with delayed-type hypersensitivity. Science (1966) 153:80-2. doi: $10.1126 /$ science.153.3731.80

15. David JR. Delayed hypersensitivity in vitro: its mediation by cell-free substances formed by lymphoid cell-antigen interaction. Proc Natl Acad Sci USA. (1966) 56:72-7. doi: 10.1073/pnas.56.1.72

16. Carswell EA, Old LJ, Kassel RL, Green S, Fiore N, Williamson B. An endotoxin-induced serum factor that causes necrosis of tumors. Proc Natl Acad Sci USA. (1975) 72:3666-70. doi: 10.1073/pnas.72.9.3666

17. Hitchcock G, Isaacs A. Protection of mice against the lethal action of an encephalitis virus. BMJ (1960) 2:1268-70. doi: 10.1136/bmj.2.5208.1268

18. Hitchcock G, Porterfield JS. The production of interferon in brains of mice infected with an arthropod-borne virus. Virology (1961) 13:363-5. doi: 10.1016/0042-6822(61)90155-6

19. Cohen S, Bigazzi PE, Yoshida T. Similarities of T cell function in cellmediated immunity and antibody production. Cell Immunol. (1974) 12:1509. doi: 10.1016/0008-8749(74)90066-5
(IoPPN), KCL. OP is funded by OBELIX (Obesity, Lifestyle and Learning from Extreme Phenotypes), a research framework within the Biomedical Research Centre (BRC) of the South London and Maudsley NHS Foundation Trust (SLaM) and the IoPPN.

20. Blalock JE, Smith EM. Human leukocyte interferon (HuIFN- $\alpha)$ : Potent endorphin-like opioid activity. Biochem Biophys Res Commun. (1981) 101:472-478. doi: 10.1016/0006-291x(81)91284-5

21. Smith EM, Dion LD, Blalock JE. Opiate receptor mediated effects of IFNalpha and lymphocyte derived endorphin-like peptides. Progr Clin Biol Res. (1985) 192:259-264. doi

22. Ankel H, Chany C, Galliot B, Chevalier MJ, Robert M. Antiviral effect of interferon covalently bound to sepharose. Proc Natl Acad Sci USA. (1973) 70:2360-3. doi: 10.1073/pnas.70.8.2360

23. Himmerich H. Plasma levels of tumor necrosis factor $\alpha$ and soluble tumor necrosis factor receptors in patients with narcolepsy. Arch Internal Med. (2006) 166:1739. doi: 10.1001/archinte.166.16.1739

24. Himmerich H. Activity of the TNF- $\alpha$ System in patients with brain disorders and during psychopharmacological treatment. Curr Pharmaceut Anal. (2007) 3:1-5. doi: 10.2174/157341207779802412

25. Yalow RS, Berson SA. Assay of Plasma insulin in human subjects by immunological methods. Nature (1959) 184:1648-9. doi: 10.1038/1841648b0

26. Van Weemen BK, Schuurs AHWM. Immunoassay using antigen-enzyme conjugates. FEBS Lett. (1971) 15:232-6. doi: 10.1016/0014-5793(71)80319-8

27. Engvall E, Perlmann P. Enzyme-linked immunosorbent assay (ELISA) quantitative assay of immunoglobulin G. Immunochemistry (1971) 8:871-4 doi: 10.1016/0019-2791(71)90454-x

28. Keustermans GCE, Hoeks SBE, Meerding, Jenny M., Prakken BJ, de Jager W. Cytokine assays: an assessment of the preparation and treatment of blood and tissue samples. Methods (2013) 61:10-17. doi: 10.1016/j.ymeth.2013.04.005

29. Cohen SN, Chang ACY, Boyer HW, Helling RB. Construction of biologically functional bacterial plasmids in vitro. Proc Natl Acad Sci USA. (1973) 70:3240-4. doi: 10.1073/pnas.70.11.3240

30. Otto B. Recombinant human interferons. Arzneimittelforschung (1985) $35: 1750-2$.

31. Capuron L, Miller AH. Immune system to brain signaling: neuropsychopharmacological implications. Pharmacol Ther. (2011) 130:226-38. doi: 10.1016/j.pharmthera.2011.01.014

32. Himmerich H, Fulda S, Linseisen J, Seiler H, Wolfram G, Himmerich S, et al. Depression, comorbidities and the TNF- $\alpha$ system. Eur Psychiatry (2008) 23:421-9. doi: 10.1016/j.eurpsy.2008.03.013

33. Schmidt FM, Lichtblau N, Minkwitz J, Chittka T, Thormann J, Kirkby $\mathrm{KC}$, et al. Cytokine levels in depressed and non-depressed subjects, and masking effects of obesity. J Psychiatr Res. (2014) 55:29-34. doi: 10.1016/j.jpsychires.2014.04.021

34. Hussein S, Himmerich H, Willmund GD, Ibrahim MAA, Dalton B. A systematic review of tumor necoris factor- $\alpha$ in post-traumatic stress disorder: evidence from human and animal studies. Psychiatr Danub. (2017) 29:40720. doi: 10.24869/psyd.2017.407

35. Waheed A, Dalton B, Wesemann U, Ibrahim MAA, Himmerich $\mathrm{H}$. A systematic review of interleukin- $1 \beta$ in post-traumatic stress disorder: evidence from human and animal studies. J Interfer Cytokine Res. (2018) 38:1-11. doi: 10.1089/jir.2017.0088

36. Passos IC, Vasconcelos-Moreno MP, Costa LG, Kunz M, Brietzke E, Quevedo $\mathrm{J}$, et al. Inflammatory markers in post-traumatic stress disorder: a systematic review, meta-analysis, and meta-regression. Lancet Psychiatry (2015) 2:100212. doi: 10.1016/S2215-0366(15)00309-0

37. Dalton B, Bartholdy S, Robinson L, Solmi M, Ibrahim MAA, Breen G, et al. A meta-analysis of cytokine concentrations in eating disorders. J Psychiatr Res. (2018) 103:252-64. doi: 10.1016/j.jpsychires.2018.06.002

38. Goldsmith DR, Rapaport MH, Miller BJ. A meta-analysis of blood cytokine network alterations in psychiatric patients: comparisons between 
schizophrenia, bipolar disorder and depression. Mol Psychiatry (2016) 21:1696-709. doi: 10.1038/mp.2016.3

39. Modabbernia A, Taslimi S, Brietzke E, Ashrafi M. Cytokine alterations in bipolar disorder: a meta-analysis of 30 studies. Biol Psychiatry (2013) 74:15-25. doi: 10.1016/j.biopsych.2013.01.007

40. Gray SM, Bloch MH. Systematic review of proinflammatory cytokines in obsessive-compulsive disorder. Curr Psychiatry Rep. (2012) 14:220-8. doi: 10.1007/s11920-012-0272-0

41. Leonard WJ, Lin JX. Cytokine receptor signaling pathways. J Allergy Clin Immunol. (2000) 105:877-88. doi: 10.1067/mai.2000.106899

42. Koch K-C, Ye K, Clark BD, Dinarello CA. Interleukin 4 (IL) 4 up-regulates gene and surface IL 1 receptor type I in murine T helper type 2 cells. Eur $J$ Immunol. (1992) 22:153-7. doi: 10.1002/eji.1830220123

43. Kasakura S. A role for T-helper type 1 and type 2 cytokines in the pathogenesis of various human diseases. Rinsho Byori (1998) 46:915-21.

44. Cejková S, Králová Lesná I, Froněk J, Králová A, Poledne R. Pro-inflammatory gene expression in adipose tissue in patients with atherosclerosis. Atherosclerosis (2016) 252:e174. doi: 10.1016/j.atherosclerosis.2016.07.820

45. Cray C, Zaias J, Altman NH. Acute phase response in animals: a review. Comp Med. (2009) 59:517-26.

46. Perskidskii I, Barshtein I. Biological manifestations of the tumor necrosis factor effect and its role in the pathogenesis of various diseases. Arkhiv Patologii (1992) 52:5-10.

47. Del Prete G. Human Th1 and Th2 lymphocytes: their role in the pathophysiology of atopy. Allergy (1992) 47:450-5.

48. Tracey MDKJ, Cerami PDA. Tumor necrosis factor: a pleiotropic cytokine and therapuetic target. Ann Rev Med. (1994) 45:491-503. doi: 10.1146/annurev.med.45.1.491

49. Hurdayal R, Ndlovu HH, Revaz-Breton M, Parihar SP, Nono JK, Govender $\mathrm{M}$, et al. IL-4-producing B cells regulate $\mathrm{T}$ helper cell dichotomy in type 1and type 2-controlled diseases. Proc Natl Acad Sci USA. (2017) 114:E8430-9. doi: $10.1073 /$ pnas. 1708125114

50. Noma T. Function, molecular structure and gene expression of IL-4. Nihon Rinsho. (1992) 50:1787-94.

51. Aggarwal BB. Signalling pathways of the TNF superfamily: a double-edged sword. Nat Rev Immunol. (2003) 3:745-56. doi: 10.1038/nri1184

52. Kicielinska J, Pajtasz-Piasecka E. The role of IL-10 in the modulation of the immune response in normal conditions and the tumor environment. Postepy Higieny Med Doświadczal. (2014) 68:879-92. doi: 10.5604/17322693.1111123

53. Bruserud $\varnothing$, Hamann W, Patel S, Ehninger G, Pawelec G. IL2and IL4-dependent proliferation of T-cell clones derived early after allogeneic bone marrow transplantation: Studies of patients with chronic myelogenous leukaemia. Eur J Haematol. (1992) 48:221-7. doi: 10.1111/j.1600-0609.1992.tb01589.x

54. Boraschi D, Censini S, Bartalini M, Ghiara P, Tagliabue A. Arachidonic acid metabolism in macrophages: regulation by interferons and interleukin 1. Int J Immunopharmacol. (1985) 7:359. doi: 10.1016/0192-0561(85)90339-x

55. Munk ME, Emoto M. Functions of T-cell subsets and cytokines in mycobacterial infections. Eur Respir J Suppl. (1995) 20:668s-75s.

56. Georas SN. T-helper cell type-2 regulation in allergic disease. Eur Respir J. (2005) 26:1119-37. doi: 10.1183/09031936.05.00006005

57. Ito T, Wang Y-H, Duramad O, Hori T, Delespesse GJ, Watanabe N, et al. TSLP-activated dendritic cells induce an inflammatory T helper type 2 cell response through OX40 ligand. J Exp Med. (2005) 202:1213-23. doi: 10.1084/jem.20051135

58. Kane B, Fowler SJ, Niven R. Refractory asthma - beyond step 5, the role of new and emerging adjuvant therapies. Chronic Respir Dis. (2015) 12:69-77. doi: $10.1177 / 1479972314562210$

59. Krumm B, Xiang Y, Deng J. Structural biology of the IL-1 superfamily: key cytokines in the regulation of immune and inflammatory responses. Protein Sci. (2014) 23:526-38. doi: 10.1002/pro.2441

60. Lorentz A, Bischoff SC. Regulation of human intestinal mast cells by stem cell factor and IL-4. Immunol Rev. (2001) 179:57-60. doi: $10.1034 / j .1600-065 x .2001 .790106 . x$

61. Howren MB, Lamkin DM, Suls J. Associations of depression with C-reactive protein, IL-1, and IL-6: a meta-analysis. Psychosomatic Med. (2009) 71:17186. doi: $10.1097 /$ psy.0b013e3181907c1b
62. Haase H, Kruse A, Rink L, editors. Die Regulation des Immunsystems und immunprivilegierte Organe. In: Immunologie für Einsteiger. Berlin; Heidelberg: Springer (2015). p. 101-20.

63. Breitbart W, Rosenfeld B, Tobias K, Pessin H, Ku GY, Yuan J, et al. Depression, cytokines, and pancreatic cancer. Psycho Oncol. (2013) 23:33945. doi: $10.1002 /$ pon. 3422

64. Caraci F, Spampinato SF, Morgese MG, Tascedda F, Salluzzo MG, Giambirtone MC, et al. Neurobiological links between depression and AD: The role of TGF-betal signaling as a new pharmacological target. Pharmacol Res. (2018) 130:374-84. doi: 10.1016/j.phrs.2018.02.007

65. Leonard WJ, Wan CK. IL-21 Signaling in immunity. F1000Res. (2016) 5:224. doi: 10.12688/f1000research.7634.1

66. Alabbas SY, Begun J, Florin TH, Oancea I. The role of IL-22 in the resolution of sterile and nonsterile inflammation. Clin Transl Immunol. (2018) 7:e1017. doi: $10.1002 / \mathrm{cti} 2.1017$

67. Juncal-Ruiz M, Riesco-Dávila L, Ortiz-García de la Foz V, Martínez-Garcia O, Ramírez-Bonilla M, Ocejo-Viñals JG, et al. Comparison of the antiinflammatory effect of aripiprazole and risperidone in 75 drug-naïve first episode psychosis individuals: A 3 months randomized study. Schizophr Res. (2018) 202:226-33. doi: 10.1016/j.schres.2018.06.039

68. Lenze EJ, Mulsant BH, Blumberger DM, Karp JF, Newcomer JW, Anderson SJ, et al. Efficacy, safety, and tolerability of augmentation pharmacotherapy with aripiprazole for treatment-resistant depression in late life: a randomised, double-blind, placebo-controlled trial. Lancet (2015) 386:2404-12. doi: 10.1016/s0140-6736(15)00308-6

69. Munzer A, Sack U, Mergl R, Schönherr J, Petersein C, Bartsch S, et al. Impact of antidepressants on cytokine production of depressed patients in vitro. Toxins (2013) 5:2227-40. doi: 10.3390/toxins5112227

70. Himmerich H, Schneider F. Psychoimmunologie. In: Schneider F, editors. Facharztwissen Psychiatrie, Psychosomatik und Psychotherapie. Berlin: Springer Berlin Heidelberg (2016). p. 535-40.

71. Korn T, Bettelli E, Oukka M, Kuchroo VK. IL-17 and Th17 Cells. Ann Rev Immunol. (2009) 27:485-517. doi: 10.1146/annurev.immunol.021908.132710

72. Eyerich K, Dimartino V, Cavani A. IL-17 and IL-22 in immunity: driving protection and pathology. Eur J Immunol. (2017) 47:607-14. doi: $10.1002 /$ eji.201646723

73. Dons EM, Raimondi G, Cooper DKC, Thomson AW. Induced regulatory T cells: mechanisms of conversion and suppressive potential. Hum Immunol. (2012) 73:328-34. doi: 10.1016/j.humimm.2011.12.011

74. Cheon Y-H, Lee S-G, Kim M, Kim H-O, Sun Suh Y, Park K-S, et al. The association of disease activity, pro-inflammatory cytokines, and neurotrophic factors with depression in patients with rheumatoid arthritis. Brain Behav Immun. (2018) 73:274-81. doi: 10.1016/j.bbi.2018.05.012

75. Song C, Luchtman D, Kang Z, Tam EM, Yatham LN, Su K-P, et al. Enhanced inflammatory and T-helper-1 type responses but suppressed lymphocyte proliferation in patients with seasonal affective disorder and treated by light therapy. J Affect Disord. (2015) 185:90-6. doi: 10.1016/j.jad.2015.06.003

76. Dahl J, Ormstad H, Aass HCD, Malt UF, Bendz LT, Sandvik L, et al. The plasma levels of various cytokines are increased during ongoing depression and are reduced to normal levels after recovery. Psychoneuroendocrinology (2014) 45:77-86. doi: 10.1016/j.psyneuen.2014.03.019

77. Mao R, Zhang C, Chen J, Zhao G, Zhou R, Wang F, et al. Different levels of pro- and anti-inflammatory cytokines in patients with unipolar and bipolar depression. J Affect Disord. (2018) 237:65-72. doi: 10.1016/j.jad.2018.04.115

78. de Waal Malefyt R, Figdor CG, Huijbens R, Mohan-Peterson S, Bennett B, Culpepper J, et al. Effects of IL-13 on phenotype, cytokine production, and cytotoxic function of human monocytes. Comparison with IL-4 and modulation by IFN-gamma or IL-10. J Immunol. (1993) 151:6370-81.

79. Tilg H, Peschel C. Interferon-alpha and its effects on the cytokine cascade: a pro- and anti-inflammatory cytokine. Leukem Lymphoma (1996) 23:55-60. doi: $10.3109 / 10428199609054802$

80. D'Mello C, Le T, Swain MG. Cerebral microglia recruit monocytes into the brain in response to tumor necrosis factoralpha signaling during peripheral organ inflammation. J Neurosci. (2009). 29:7. doi: 10.1523/JNEUROSCI.3567-08.2009

81. Lichtblau N, Schmidt FM, Schumann R, Kirkby KC, Himmerich H. Cytokines as biomarkers in depressive disorder: current 
standing and prospects. Int Rev Psychiatry (2013) 25:592-603. doi: $10.3109 / 09540261.2013 .813442$

82. Dunn AJ, Wang J. Cytokine effects on CNS biogenic amines. Neuroimmunomodulation (1995) 2:319-28. doi: 10.1159/000097211

83. Dunn AJ, Wang J, Ando T. Effects of cytokines on cerebral neurotransmission. Comparison with the effects of stress. Adv Exp Med Biol. (1999) 461:117-27. doi: 10.1007/978-0-585-37970-8_8

84. Anisman H, Matheson K. Stress, depression, and anhedonia: caveats concerning animal models. Neurosci Behav Rev. (2005) 29:525-46. doi: 10.1016/j.neubiorev.2005.03.007

85. Musselman DL, Lawson DH, Gumnick JF, Manatunga AK, Penna $\mathrm{S}$, Goodkin RS, et al. Paroxetine for the prevention of depression induced by high-dose interferon alfa. N Engl J Med. (2001) 344:961-6. doi: 10.1056/NEJM200103293441303

86. Raison CL, Woolwine BJ, Demetrashvili MF, Borisov AS, Weinreib R, Staab $J P$, et al. Paroxetine for prevention of depressive symptoms induced by interferon-alpha and ribavirin for hepatitis C. Aliment Pharmacol Ther. (2007) 25:1163-74. doi: 10.1111/j.1365-2036.2007.03316.x

87. Bonaccorso S, Marino V, Puzella A, Pasquini M, Biondi M, Artini M, et al. Increased depressive ratings in patients with hepatitis $\mathrm{c}$ receiving interferon- $\alpha$-based immunotherapy are related to interferon- $\alpha$-induced changes in the serotonergic system. J Clin Psychopharmacol. (2002) 22:86-90. doi: 10.1097/00004714-200202000-00014

88. Capuron L, Musselman DL, Lawson DH, Nemeroff CB, Fuchs D, Miller AH. Interferon-alpha-induced changes in tryptophan metabolism. relationship to depression and paroxetine treatment. Biol Psychiatry (2003) 54:906-14. doi: 10.1016/S0006-3223(03)00173-2

89. Zhu C-B, Blakely RD, Hewlett WA. The Proinflammatory cytokines interleukin-1beta and tumor necrosis factor-alpha activate serotonin transporters. Neuropsychopharmacology (2006) 31:2121-31. doi: 10.1038/sj.npp.1301029

90. Zhu C-B, Carneiro AM, Dostmann WR, Hewlett WA, Blakely RD. p38 MAPK activation elevates serotonin transport activity via a traffickingindependent, protein phosphatase 2A-dependent process. J Biol Chem. (2005) 280:15649-58. doi: 10.1074/jbc.m410858200

91. Zhu C-B, Lindler KM, Owens AW, Daws LC, Blakely RD, Hewlett WA. Interleukin-1 receptor activation by systemic lipopolysaccharide induces behavioral despair linked to MAPK regulation of CNS serotonin transporters. Neuropsychopharmacology (2010) 35:2510-20. doi: $10.1038 / n p p .2010 .116$

92. Morón JA, Zakharova I, Ferrer JV, Merrill GA, Hope B, Lafer EM, et al. Mitogen-activated protein kinase regulates dopamine transporter surface expression and dopamine transport capacity. J Neurosci. (2003) 23:8480-8. doi: 10.1523/jneurosci.23-24-08480.2003

93. Capuron L, Pagnoni G, Drake DF, Woolwine BJ, Spivey JR, Crowe RJ, et al. Dopaminergic mechanisms of reduced basal ganglia responses to hedonic reward during interferon alfa administration. Arch General Psychiatry (2012) 69:1044. doi: 10.1001/archgenpsychiatry.2011.2094

94. Ida T, Hara M, Nakamura Y, Kozaki S, Tsunoda S, Ihara H. Cytokineinduced enhancement of calcium-dependent glutamate release from astrocytes mediated by nitric oxide. Neurosci Lett. (2008) 432:232-6. doi: 10.1016/j.neulet.2007.12.047

95. Matute C, Domercq M, Sánchez-Gómez, MV. Glutamate-mediated glial injury: Mechanisms and clinical importance. Glia (2006) 53:675. doi: $10.1002 /$ glia. 20323

96. Lee M, Schwab C, McGeer PL. Astrocytes are GABAergic cells that modulate microglial activity. Glia (2010) 59:152-65. doi: 10.1002/glia.21087

97. Dale RC, Merheb V, Pillai S, Wang D, Cantrill L, Murphy TK, et al. Antibodies to surface dopamine-2 receptor in autoimmune movement and psychiatric disorders. Brain (2012) 135:3453-68. doi: 10.1093/brain/aws256

98. Tanaka S, Kuratsune H, Hidaka Y, Hakariya Y, Tatsumi K-I, Takano T, et al. Autoantibodies against muscarinic cholinergic receptor in chronic fatigue syndrome. Int J Mol Med. (2003) 12:225-30. doi: 10.3892/ijmm.12.2.225

99. Besedovsky HO, Del Rey A. Immune-neuro-endocrine interactions: facts and hypotheses. Endocr Rev. (1996) 17:64-102. doi: 10.1210/edrv-17-1-64

100. Pariante CM, Miller AH. Glucocorticoid receptors in major depression: relevance to pathophysiology and treatment. Biol Psychiatry (2001) 49:391404. doi: $10.1016 / \mathrm{s} 0006-3223(00) 01088-\mathrm{x}$
101. Pace TWW, Hu F, Miller AH. Cytokine-effects on glucocorticoid receptor function: Relevance to glucocorticoid resistance and the pathophysiology and treatment of major depression. Brain Behav Immun. (2007) 21:9-19. doi: 10.1016/j.bbi.2006.08.009

102. Sephton SE. Diurnal cortisol rhythm as a predictor of breast cancer survival. J Natl Cancer Inst. (2000) 92:994-1000. doi: 10.1093/jnci/92.12.994

103. Matthews K, Schwartz J, Cohen S, Seeman T. Diurnal cortisol decline is related to coronary calcification: CARDIA study. Psychosomatic Med. (2006) 68:657-61. doi: 10.1097/01.psy.0000244071.42939.0e

104. Raison CL, Borisov AS, Woolwine BJ, Massung B, Vogt G, Miller AH. Interferon-alpha effects on diurnal hypothalamic-pituitary-adrenal axis activity: relationship with proinflammatory cytokines and behavior. Mol Psychiatry (2010) 15:535-47. doi: 10.1038/mp.2008.58

105. Hardingham GE, Fukunaga Y, Bading H. Extrasynaptic NMDARs oppose synaptic NMDARs by triggering CREB shut-off and cell death pathways. Nat Neurosci. (2002) 5:405-14. doi: 10.1038/nn835

106. Berthold-Losleben M, Heitmann S, Himmerich H. Anti-inflammatory drugs in psychiatry. Inflamm Allergy Drug Targets (2009) 8:266-76. doi: $10.2174 / 187152809789352221$

107. Alexander GE, Crutcher MD, DeLong MR. Basal ganglia-thalamocortical circuits: parallel substrates for motor, oculomotor, "prefrontal" and "limbic" functions. Progress Brain Res. (1991) 85:119-46.

108. Eisenberger NI, Lieberman MD. Why rejection hurts: a common neural alarm system for physical and social pain. Trends Cogn Sci. (2004) 8:294-300. doi: 10.1016/j.tics.2004.05.010

109. Juengling FD, Ebert D, Gut O, Engelbrecht MA, Rasenack J, Nitzsche EU, et al. Prefrontal cortical hypometabolism during low-dose interferon alpha treatment. Psychopharmacology (2000) 152:383-9. doi: $10.1007 /$ s002130000549

110. Capuron L, Pagnoni G, Demetrashvili MF, Lawson DH, Fornwalt FB, Woolwine B, et al. Basal ganglia hypermetabolism and symptoms of fatigue during interferon- $\alpha$ therapy. Neuropsychopharmacology (2007) 32:2384-92. doi: 10.1038/sj.npp.1301362

111. Brydon L, Harrison NA, Walker C, Steptoe A, Critchley HD. Peripheral inflammation is associated with altered substantia nigra activity and psychomotor slowing in humans. Biol Psychiatry (2008) 63:1022-9. doi: 10.1016/j.biopsych.2007.12.007

112. Majer M, Welberg LAM, Capuron L, Pagnoni G, Raison CL, Miller AH. IFN-alpha-induced motor slowing is associated with increased depression and fatigue in patients with chronic hepatitis C. Brain Behav Immun. (2008) 22:870-80. doi: 10.1016/j.bbi.2007.12.009

113. Harrison NA, Brydon L, Walker C, Gray MA, Steptoe A, Critchley HD. Inflammation causes mood changes through alterations in subgenual cingulate activity and mesolimbic connectivity. Biol Psychiatry (2009) 66:407-14. doi: 10.1016/j.biopsych.2009.03.015

114. Capuron L, Pagnoni G, Demetrashvili M, Woolwine B, Nemeroff C, Berns G, et al. Anterior cingulate activation and error processing during interferon-alpha treatment. Biol Psychiatry (2005) 58:190-6. doi: 10.1016/j.biopsych.2005.03.033

115. Himmerich H, Fischer J, Bauer K, Kirkby KC, Sack U, Krugel U. Stressinduced cytokine changes in rats. Eur Cytokine Network (2013) 24:97-103. doi: 10.1684/ecn.2013.0338

116. Munkholm K, Brauner J, Kessing LV, Vinberg M. Cytokines in bipolar disorder vs. healthy control subjects: a systematic review and meta-analysis. J Psychiatr Res. (2013) 47:1119-33. doi: 10.1016/j.jpsychires.2013.05.018

117. Himmerich H, Minkwitz J, Kirkby K. Weight gain and metabolic changes during treatment with antipsychotics and antidepressants. Endocr Metabol Immune Disorder Drug Targets (2015) 15:252-60. doi: $10.2174 / 1871530315666150623092031$

118. Cross-Disorder Group of the Psychiatric Genomics C. Identification of risk loci with shared effects on five major psychiatric disorders: a genomewide analysis. Lancet (2013) 381:1371-9. doi: 10.1016/S0140-6736(12) 62129-1

119. Piliero LM. T-cell homeostasis in humans with thymic hypoplasia due to chromosome 22q11.2 deletion syndrome. Blood (2003) 103:1020-5. doi: 10.1182/blood-2003-08-2824

120. Gimeno D, Kivimäki M, Brunner EJ, Elovainio M, De Vogli R, Steptoe A, et al. Associations of C-reactive protein and interleukin-6 with cognitive 
symptoms of depression: 12-year follow-up of the Whitehall II study. Psychological Med. (2008) 39:413. doi: 10.1017/s0033291708003723

121. Ramirez G, Toro R, Dobeli H, von Bernhardi R. Protection of rat primary hippocampal cultures from A beta cytotoxicity by pro-inflammatory molecules is mediated by astrocytes. Neurobiol Dis. (2005) 19:243-54. doi: 10.1016/j.nbd.2005.01.007

122. Mufaddel A, Omer AA, Salem MO. Psychiatric aspects of infectious diseases. Open J Psychiatry (2014) 04:202-17. doi: 10.4236/ojpsych.2014.43027

123. Steinberg H, Himmerich H. Emil Kraepelin's habilitation and his thesis: a pioneer work for modern systematic reviews, psychoimmunological research and categories of psychiatric diseases. World J Biol Psychiatry (2013) 14:24857. doi: 10.3109/15622975.2011.623717

124. Himmerich H, Kohls E, Hegerl U, Rummel-Kluge C. Prädiktive Faktoren der Depression und ihrer Therapie. Der Nervenarzt (2014) 85:1249-54. doi: 10.1007/s00115-014-4048-0

125. Himmerich H, Lichtblau N. Prävention psychischer Erkrankungen am Beispiel der Depression. In: Hans-Wolfgang Hoefert CKH, editors. Krankheitsprävention in der Kontroverse. Lengerich: Pabst Science Publishers (2014). p. 166-81.

126. Muñoz RF, Cuijpers P, Smit F, Barrera AZ, Leykin Y. Prevention of major depression. Ann Rev Clin Psychol. (2010) 6:181-212. doi: 10.1146/annurev-clinpsy-033109-132040

127. Mills NT, Scott JG, Wray NR, Cohen-Woods S, Baune BT. Research review: the role of cytokines in depression in adolescents: a systematic review. J Child Psychol Psychiatry (2013) 54:816-35. doi: 10.1111/jcpp.12080

128. Fonken LK, Xu X, Weil ZM, Chen G, Sun Q, Rajagopalan S, et al. Air pollution impairs cognition, provokes depressive-like behaviors and alters hippocampal cytokine expression and morphology. Mol Psychiatry (2011) 16:987-95. doi: $10.1038 / \mathrm{mp} .2011 .76$

129. Kristiansson M, Sörman K, Tekwe C, Calderón-Garcidueñas L. Urban air pollution, poverty, violence and health - Neurological and immunological aspects as mediating factors. Environ Res. (2015) 140:511-3. doi: 10.1016/j.envres.2015.05.013

130. Measelle JR, Ablow JC. Contributions of early adversity to pro-inflammatory phenotype in infancy: the buffer provided by attachment security. Attach Hum Dev. (2018) 20:1-23. doi: 10.1080/14616734.2017.1362657

131. Hintikka J, Lehto SM, Niskanen L, Huotari A, Herzig KH, Koivumaa-Honkanen $\mathrm{H}$, et al. Unemployment and ill health: a connection through inflammation? BMC Public Health (2009) 9:410. doi: 10.1186/1471-2458-9-410

132. Leonard B, Maes M. Mechanistic explanations how cell-mediated immune activation, inflammation and oxidative and nitrosative stress pathways and their sequels and concomitants play a role in the pathophysiology of unipolar depression. Neurosci Biobehav Rev. (2012) 36:764-85. doi: 10.1016/j.neubiorev.2011.12.005

133. Grudet C, Malm J, Westrin A, Brundin L. Suicidal patients are deficient in vitamin $\mathrm{D}$, associated with a pro-inflammatory status in the blood. Psychoneuroendocrinology (2014) 50:210-9. doi: 10.1016/j.psyneuen.2014.08.016. [Epub ahead of print].

134. Amini S, Jafarirad S, Amani R. Postpartum depression and vitamin D: a systematic review. Crit Rev Food Sci Nutr. (2018). doi: 10.1080/10408398.2017.1423276. [Epub ahead of print].

135. Husted KS, Bouzinova EV. The importance of $n-6 / n-3$ fatty acids ratio in the major depressive disorder. (2016) 52:139-47. doi: 10.1016/j.medici.2016.05.003

136. Dinan TG, Cryan JF. The microbiome-gut-brain axis in health and disease. Gastroenterol Clin North Am. (2017) 46:77-89. doi: 10.1016/j.gtc.2016. 09.007

137. Schirmer M, Kumar V, Netea MG, Xavier RJ. The causes and consequences of variation in human cytokine production in health. Curr Opin Immunol. (2018) 54:50-8. doi: 10.1016/j.coi.2018.05.012

138. Rohleder N. Stimulation of systemic low-grade inflammation by psychosocial stress. Psychosomatic Med. (2014) 76:181-9. doi: 10.1097/psy.0000000000000049

139. Menard C, Pfau ML, Hodes GE, Kana V, Wang VX, Bouchard S, et al. Social stress induces neurovascular pathology promoting depression. Nat Neurosci. (2017) 20:1752-60. doi: 10.1038/s41593-017-0010-3
140. Levine ME, Cole SW, Weir DR, Crimmins EM. Childhood and later life stressors and increased inflammatory gene expression at older ages. Soc Sci Med. (2015) 130:16-22. doi: 10.1016/j.socscimed.2015.01.030

141. Cohen M, Granger S, Fuller-Thomson E. The association between bereavement and biomarkers of inflammation. Behav Med. (2014) 41:49-59. doi: 10.1080/08964289.2013.866539

142. Jaremka LM, Lindgren ME, Kiecolt-Glaser JK. Synergistic relationships amongst stress, depression, and troubled relationships: Insights from psychoneuroimmunology. Depress Anxiety (2013) 30:288-96. doi: $10.1002 /$ da. 22078

143. O'Connor TG, Scheible K, Sefair AV, Gilchrist M, Blackmore ER, Winter MA, et al. Immune and neuroendocrine correlates of temperament in infancy. Dev Psychopathol. (2017) 29:1589-600. doi: 10.1017/s0954579417001250

144. Kim HN, Kim BH, Cho J, Ryu S, Shin H, Sung J, et al. Pathway analysis of genome-wide association datasets of personality traits. Genes Brain Behav. (2015) 14:345-56. doi: 10.1111/gbb.12212

145. Golimbet VE, Alfimova MV, Korovaitseva GI, Lezheiko TV. Analysis of the association of interleukin 4 and interleukin 10 gene variants with basic personality traits. Mol Biol. (2016) 50:839-44. doi: 10.1134/s0026893316060054

146. Quagliato LA, Nardi AE. Cytokine alterations in panic disorder: a systematic review. J Affect Disord. (2018) 228:91-6. doi: 10.1016/j.jad.2017.11.094

147. Tang Z, Ye G, Chen X, Pan M, Fu J, Fu T, et al. Peripheral proinflammatory cytokines in Chinese patients with generalised anxiety disorder. $J$ Affect Disord. (2018) 225:593-8. doi: 10.1016/j.jad.2017.08.082

148. Heberlein A, Käser M, Lichtinghagen R, Rhein M, Lenz B, Kornhuber J, et al. TNF- $\alpha$ and IL- 6 serum levels: neurobiological markers of alcohol consumption in alcohol-dependent patients? Alcohol (2014) 48:671-6. doi: 10.1016/j.alcohol.2014.08.003

149. Moreira FP, Medeiros JR, Lhullier AC, Souza LD, Jansen K, Portela LV, et al. Cocaine abuse and effects in the serum levels of cytokines IL-6 and IL-10. Drug Alcohol Depend. 158:181-5. doi: 10.1016/j.drugalcdep.2015. 11.024

150. Lambertsen KL, Biber K, Finsen B. Inflammatory cytokines in experimental and human stroke. J Cerebr Blood Flow Metabol. (2012) 32:1677-98. doi: $10.1038 / \mathrm{jcbfm} .2012 .88$

151. Ethemoglu O, Ay H, Koyuncu I, Gönel A. Comparison of cytokines and prooxidants/antioxidants markers among adults with refractory versus well-controlled epilepsy: a cross-sectional study. Seizure (2018) 60:105-9. doi: 10.1016/j.seizure.2018.06.009

152. Koh S. Role of neuroinflammation in evolution of childhood epilepsy. J Child Neurol. (2018) 33:64-72. doi: 10.1177/0883073817739528

153. Kaur K, Gill JS, Bansal PK, Deshmukh R. Neuroinflammation - A major cause for striatal dopaminergic degeneration in Parkinson's disease. J Neurol Sci. (2017) 381:308-14. doi: 10.1016/j.jns.2017.08.3251

154. Tiwari PC, Pal R. The potential role of neuroinflammation and transcription factors in Parkinson disease. Dialog Clin Neurosci. (2017) 19:71-80.

155. Schreiner B, Becher B. Perspectives on cytokine-directed therapies in multiple sclerosis. Swiss Med Week. (2015) 145:w14199. doi: 10.4414/smw.2015.14199

156. Rose-John S, Winthrop K, Calabrese L. The role of IL-6 in host defence against infections: immunobiology and clinical implications. Nat Rev Rheumatol. (2017) 13:399-409. doi: 10.1038/nrrheum.2017.83

157. Arango-Duque G, Descoteaux A. Macrophage cytokines: involvement in immunity and infectious diseases. Front Immunol. (2014) 5:491. doi: 10.3389/fimmu.2014.00491

158. Li S, Yang D, Peng T, Wu Y, Tian Z, Ni B. Innate lymphoid cellderived cytokines in autoimmune diseases. J Autoimmun. (2017) 83:62-72. doi: 10.1016/j.jaut.2017.05.001

159. Kuwabara T, Ishikawa F, Kondo M, Kakiuchi T. The Role of IL-17 and related cytokines in inflammatory autoimmune diseases. Mediator Inflamm. (2017) 2017:1-11. doi: 10.1155/2017/3908061

160. Igaz P, Glaz E, Racz K. Cytokines in diseases of the endocrine system. Cell Biol Int. (2000) 24:663-8. doi: 10.1006/cbir.2000.0536

161. Smyth MJ, Cretney E, Kershaw MH, Hayakawa Y. Cytokines in cancer immunity and immunotherapy. Immunol Rev. (2004) 202:275-93. doi: $10.1111 / j .0105-2896.2004 .00199 . x$ 
162. Schmidt FM, Weschenfelder J, Sander C, Minkwitz J, Thormann J, Chittka $\mathrm{T}$, et al. Inflammatory cytokines in general and central obesity and modulating effects of physical activity. PLOS ONE (2015) 10:e0121971. doi: 10.1371/journal.pone.0121971

163. Thormann J, Chittka T, Minkwitz J, Kluge M, Himmerich H. Obesity and depression: an overview on the complex interactions of two diseases. Fortschr Neurol Psychiatr. (2013) 81:145-53. doi: 10.1055/s-0032-1330351

164. Herder C, Schmitt A, Budden F, Reimer A, Kulzer B, Roden M, et al. Association between pro- and anti-inflammatory cytokines and depressive symptoms in patients with diabetes-potential differences by diabetes type and depression scores. Transl Psychiatry (2018) 7:11. doi: 10.1038/s41398-017-0009-2

165. Neri M, Fineschi V, Di Paolo M, Pomara C, Riezzo I, Turillazzi E, et al. Cardiac oxidative stress and inflammatory cytokines response after myocardial infarction. Curr Vasc Pharmacol. (2015) 13:26-36. doi: 10.2174/15701611113119990003

166. Sousa A, Raposo F, Fonseca S, Valente L, Duarte F, Gonçalves M, et al. Measurement of cytokines and adhesion molecules in the first 72 hours after severe trauma: association with severity and outcome. Disease Marker. (2015) 2015:1-8. doi: 10.1155/2015/747036

167. Winckler FC, Braz AMM, Silva VND, Golim MA, Andrade VG, Machado PEA, et al. Influence of the inflammatory response on treatment of hepatitis C with triple therapy. Rev Soc Bras Med Trop. (2018) 51:731-6. doi: 10.1590/0037-8682-0137-2018

168. Seruga B, Zhang H, Bernstein LJ, Tannock IF. Cytokines and their relationship to the symptoms and outcome of cancer. Nat Rev Cancer (2008) 8:887-99. doi: 10.1038/nrc2507

169. Alazawi W, Pirmadjid N, Lahiri R, Bhattacharya S. Inflammatory and immune responses to surgery and their clinical impact. Ann Surg. (2016) 264:73-80. doi: 10.1097/SLA.0000000000001691

170. Raj RV, Hamadani M, Szabo A, Pasquini MC, Shah NN, Drobyski WR, et al. Peripheral blood grafts for T cell-replete haploidentical transplantation increase the incidence and severity of cytokine release syndrome. Biol Blood Marrow Transplant. (2018) 24:1664-70. doi: 10.1016/j.bbmt.2018.04.010.

171. Weschenfelder J, Sander C, Kluge M, Kirkby KC, Himmerich H. The influence of cytokines on wakefulness regulation: clinical relevance, mechanisms and methodological problems. Psychiatr Danub. (2012) 24:11226.

172. Schmidt FM, Pschiebl A, Sander C, Kirkby KC, Thormann J, Minkwitz J, et al. Impact of serum cytokine levels on EEG-measured arousal regulation in patients with major depressive disorder and healthy controls. Neuropsychobiology (2016) 73:1-9. doi: 10.1159/000441190

173. Szarka A, Rigo J Jr, Lazar L, Beko G, Molvarec A. Circulating cytokines, chemokines and adhesion molecules in normal pregnancy and preeclampsia determined by multiplex suspension array. BMC Immunol. (2010) 11:59. doi: 10.1186/1471-2172-11-59

174. Sel'kov SA, Pavlov OV, Selyutin AV. Cytokines and placental macrophages in regulation of birth activity. Bull Exp Biol Med. (2000) 129:511-5. doi: $10.1007 / \mathrm{bf0} 2434861$

175. Camilleri G, Borg M, Brincat S, Schembri-Wismayer P, Brincat M, CallejaAgius J. The role of cytokines in cardiovascular disease in menopause. Climacteric (2012) 15:524-30. doi: 10.3109/13697137.2012.700743

176. Sudheimer KD, O'Hara R, Spiegel D, Powers B, Kraemer HC, Neri E, et al. Cortisol, cytokines, and hippocampal volume interactions in the elderly. Front Aging Neurosci. (2014) 6:153. doi: 10.3389/fnagi.2014.00153

177. Graham AM, Rasmussen JM, Rudolph MD, Heim CM, Gilmore JH, Styner $\mathrm{M}$, et al. Maternal systemic interleukin-6 during pregnancy is associated with newborn amygdala phenotypes and subsequent behavior at 2 years of age. Biol Psychiatry (2018) 83:109-19. doi: 10.1016/j.biopsych.2017. 05.027

178. Clark SM, Pocivavsek A, Nicholson JD, Notarangelo FM, Langenberg P, McMahon RP, et al. Reduced kynurenine pathway metabolism and cytokine expression in the prefrontal cortex of depressed individuals. J Psychiatry Neurosci. (2016) 41:386-94. doi: 10.1503/jpn.150226

179. Shadrina M, Bondarenko EA, Slominsky PA. Genetics factors in major depression disease. Front Psychiatry (2018) 9:334. doi: 10.3389/fpsyt.2018.00334
180. Crawford B, Craig Z, Mansell G, White I, Smith A, Spaull S, et al. DNA methylation and inflammation marker profiles associated with a history of depression. Hum Mol Genetics (2018) 27:2840-50. doi: 10.1093/hmg/ddy199

181. Maes M. Major depression and activation of the inflammatory response system. Adv Exp Med Biol. (1999) 461:25-46. doi: 10.1007/978-0-585-37970-8_2

182. Anisman H, Merali Z, Poulter MO, Hayley S. Cytokines as a precipitant of depressive illness: animal and human studies. Curr Pharmaceut Design (2005) 11:963-72. doi: 10.2174/1381612053381701

183. Dugue B, Leppanen E, Grasbeck R. Preanalytical factors and the measurement of cytokines in human subjects. Int J Clin Lab Res. (1996) 26:99-105.

184. Fagiolo U, Cossarizza A, Santacaterina S, Ortolani C, Monti D, Paganelli $\mathrm{R}$, et al. Increased cytokine production by peripheral blood mononuclear cells from healthy elderly people. Ann N Y Acad Sci. (1992) 663:490-3. doi: 10.1111/j.1749-6632.1992.tb38712.x

185. Fagiolo U, Cossarizza A, Scala E, Fanales-Belasio E, Ortolani C, Cozzi E, et al. Increased cytokine production in mononuclear cells of healthy elderly people. Eur J Immunol. (1993) 23:2375-8. doi: 10.1002/eji.1830230950

186. Bastard JP, Jardel C, Delattre J, Hainque B, Bruckert E, Oberlin F. Evidence for a link between adipose tissue interleukin- 6 content and serum C-reactive protein concentrations in obese subjects. Circulation (1999) 99:2221-2.

187. Wellen KE, Hotamisligil GS. Obesity-induced inflammatory changes in adipose tissue. J Clin Invest. (2003). 112:1785-8. doi: 10.1172/jci200320514

188. Capuron L, Su S, Miller AH, Bremner JD, Goldberg J, Vogt GJ, et al. Depressive symptoms and metabolic syndrome: is inflammation the underlying link? Biol Psychiatry (2008) 64:896-900. doi: 10.1016/j.biopsych.2008.05.019

189. Sweat V, Starr V, Bruehl H, Arentoft A, Tirsi A, Javier E, et al. C-reactive protein is linked to lower cognitive performance in overweight and obese women. Inflammation (2008) 31:198-207. doi: 10.1007/s10753-008-9065-3

190. Yaffe K. The metabolic syndrome, inflammation, and risk of cognitive decline. JAMA (2004) 292:2237. doi: 10.1001/jama.292.18.2237

191. Godbout J, Johnson R. Age and neuroinflammation: a lifetime of psychoneuroimmune consequences. Immunol Allergy Clin N Am. (2009) 29:321-37. doi: 10.1016/j.iac.2009.02.007

192. Layé S. Polyunsaturated fatty acids, neuroinflammation and well being. Prostaglandins Leukot Essent Fatty Acids (2010) 82:295-303. doi: 10.1016/j.plefa.2010.02.006

193. Johannsen A, Susin C, Gustafsson A. Smoking and inflammation: evidence for a synergistic role in chronic disease. Periodontol 2000 (2013) 64:111-26. doi: 10.1111/j.1600-0757.2012.00456.x

194. Kluge M, Schuld A, Schacht A, Himmerich H, Dalal MA, Wehmeier PM, et al. Effects of clozapine and olanzapine on cytokine systems are closely linked to weight gain and drug-induced fever. Psychoneuroendocrinology (2009) 34:118-28. doi: 10.1016/j.psyneuen.2008.08.016

195. Berthold-Losleben M, Himmerich $H$. The TNF-alpha system: functional aspects in depression, narcolepsy and psychopharmacology. Curr Neuropharmacol. 6:193-202. doi: 10.2174/157015908785777238

196. Shapiro PA. Management of depression after myocardial infarction. Curr. Cardiol Rep. (2015) 17:10. doi: 10.1007/s11886-015-0634-4

197. Murakami Y, Ishibashi T, Tomita E, Imamura Y, Tashiro T, Watcharanurak $\mathrm{K}$, et al. Depressive symptoms as a side effect of Interferon-alpha therapy induced by induction of indoleamine 2,3-dioxygenase 1. Sci Rep. (2016) 6:29920. doi: 10.1038/srep29920

198. Bromberg JS, Hittle L, Xiong Y, Saxena V, Smyth EM, Li L, et al. Gut microbiota-dependent modulation of innate immunity and lymph node remodeling affects cardiac allograft outcomes. JCI Insight (2018) 3:19. doi: $10.1172 /$ jci.insight. 121045

199. Reichenberg A, Yirmiya R, Schuld A, Kraus T, Haack M, Morag A, et al. Cytokine-associated emotional and cognitive disturbances in humans. Arch Gen Psychiatry (2001) 58:445-52. doi: 10.1001/archpsyc.58.5.445

200. Pace LA, Crowe SE. Complex Relationships Between Food, Diet, and the Microbiome. Gastroenterol Clin North Am. (2016) 45:253-65. doi: 10.1016/j.gtc.2016.02.004

201. Kraus T, Haack M, Schuld A, Hinze-Selch D, Koethe D, Pollmächer T. Body weight, the tumor necrosis factor system, and leptin production during 
treatment with mirtazapine or venlafaxine. Pharmacopsychiatry (2002) 35:220-5. doi: 10.1055/s-2002-36390

202. Kast RE. Anti- and pro-inflammatory considerations in antidepressant use during medical illness: bupropion lowers and mirtazapine increases circulating tumor necrosis factor-alpha levels. General Hosp Psychiatry (2003) 25:495-6. doi: 10.1016/s0163-8343(03)00093-8

203. Gupta R, Gupta K, Tripathi AK, Bhatia MS, Gupta LK. Effect of mirtazapine treatment on serum levels of brain-derived neurotrophic factor and tumor necrosis factor-a in patients of major depressive disorder with severe depression. Pharmacology (2016) 97:184-188. doi: 10.1159/000444220

204. Wijkstra J, Lijmer J, Burger H, Geddes J, Nolen WA. Pharmacological treatment for psychotic depression. Cochrane Database Syst Rev. (2013) 11:Cd004044. doi: 10.1002/14651858.CD004044.pub3

205. Sumegi A. Mood stabilizers-past, present and future. Neuropsychopharmacol Hung. (2008) 10:31-42.

206. Himmerich H, Koethe D, Schuld A, Yassouridis A, Pollmacher T. Plasma levels of leptin and endogenous immune modulators during treatment with carbamazepine or lithium. Psychopharmacology (2005) 179:447-51. doi: 10.1007/s00213-004-2038-9

207. Baumeister D, Ciufolini S, Mondelli V. Effects of psychotropic drugs on inflammation: consequence or mediator of therapeutic effects in psychiatric treatment? Psychopharmacology (2016) 233:1575-89. doi: 10.1007/s00213-015-4044-5

208. Himmerich H, Schönherr J, Fulda S, Sheldrick AJ, Bauer K, Sack U. Impact of antipsychotics on cytokine production in-vitro. J Psychiatr Res. (2011) 45:1358-65. doi: 10.1016/j.jpsychires.2011.04.009

209. Himmerich H, Bartsch S, Hamer H, Mergl R, Schönherr J, Petersein $\mathrm{C}$, et al. Impact of mood stabilizers and antiepileptic drugs on cytokine production in-vitro. J Psychiatr Res. (2013) 47:1751-9. doi: 10.1016/j.jpsychires.2013.07.026

210. Jha MK, Minhajuddin A, Gadad BS, Greer TL, Mayes TL, Trivedi MH. Interleukin 17 selectively predicts better outcomes with bupropionSSRI combination: Novel $\mathrm{T}$ cell biomarker for antidepressant medication selection. Brain Behav Immun. (2017) 66:103-10. doi: 10.1016/j.bbi.2017.07.005

211. Del Grande da Silva G, Wiener CD, Barbosa LP, Gonçalves Araujo JM, Molina ML, San Martin P, et al. Pro-inflammatory cytokines and psychotherapy in depression: Results from a randomized clinical trial. $J$ Psychiatric Res. (2016) 75:57-64. doi: 10.1016/j.jpsychires.2016.01.008
212. Lyngstad SH, Gardsjord ES, Simonsen C, Engen MJ, Romm KL, Melle I, et al. Consequences of persistent depression and apathy in first-episode psychosis - A one-year follow-up study. Comprehen Psychiatry (2018) 86:60-6. doi: 10.1016/j.comppsych.2018.07.015

213. Li Y, Xiao B, Qiu W, Yang L, Hu B, Tian X, et al. Altered expression of $\mathrm{CD} 4+\mathrm{CD} 25+$ regulatory $\mathrm{T}$ cells and its 5 -HT1a receptor in patients with major depression disorder. J Affect Disord. (2010) 124:68-75. doi: 10.1016/j.jad.2009.10.018

214. Himmerich H, Milenović S, Fulda S, Plümäkers B, Sheldrick AJ, Michel TM, et al. Regulatory $\mathrm{T}$ cells increased while IL-1 $\beta$ decreased during antidepressant therapy. J Psychiatr Res. (2010) 44:1052-7. doi: 10.1016/j.jpsychires.2010.03.005

215. Maes M, Anderson G, Kubera M, Berk M. Targeting classical IL6 signalling or IL-6trans-signalling in depression? Expert Opin Therapeut Targets (2014) 18:495-512. doi: 10.1517/14728222.2014. 888417

216. Kern S, Skoog I, Börjesson-Hanson A, Blennow K, Zetterberg H, Östling S, et al. Higher CSF interleukin-6 and CSF interleukin-8 in current depression in older women. Results from a population-based sample. Brain Behav Immun. (2014) 41:55-8. doi: 10.1016/j.bbi.2014. 05.006

217. Krügel U, Fischer J, Radicke S, Sack U, Himmerich H. Antidepressant effects of TNF- $\alpha$ blockade in an animal model of depression. J Psychiatr Res. (2013) 47:611-6. doi: 10.1016/j.jpsychires.2013.01.007

218. Schmidt FM, Kirkby KC, Himmerich H. The TNF-alpha inhibitor etanercept as monotherapy in treatment-resistant depression - report of two cases. Psychiatr Danub. (2014) 26:288-90.

Conflict of Interest Statement: The authors declare that the research was conducted in the absence of any commercial or financial relationships that could be construed as a potential conflict of interest.

Copyright (C) 2019 Himmerich, Patsalos, Lichtblau, Ibrahim and Dalton. This is an open-access article distributed under the terms of the Creative Commons Attribution License (CC BY). The use, distribution or reproduction in other forums is permitted, provided the original author(s) and the copyright owner(s) are credited and that the original publication in this journal is cited, in accordance with accepted academic practice. No use, distribution or reproduction is permitted which does not comply with these terms. 